Analyses of the genomes, transcriptomes and phenotypic characterization of Salmonella Typhimurium strains isolated from humans, food and swine in Brazil

Análises dos genomas, transcriptomas e caracterização fenotípica de linhagens de Salmonella Typhimurium isoladas de humanos, alimentos e suínos no Brasil 
UNIVERSIDADE DE SÃO PAULO

FACULDADE DE CIÊNCIAS FARMACÊUTICAS DE RIBEIRÃO PRETO

\section{Analyses of the genomes, transcriptomes and phenotypic characterization of Salmonella Typhimurium strains isolated from humans, food and swine in Brazil}

\section{Análises dos genomas, transcriptomas e caracterização fenotípica de linhagens de Salmonella Typhimurium isoladas de humanos, alimentos e suínos no Brasil}

Doctoral Thesis presented to the Graduation Program of Biosciences and Biotechnology of the School of Pharmaceutical Sciences of Ribeirão Preto/USP for the degree of Doctor in Sciences

Concentration area: Bioagents and Biotechnology Applied to Pharmacy

Candidate: Amanda Aparecida Seribelli

Supervisor: Prof ${ }^{\mathrm{a}} \mathrm{Dr}^{\mathrm{a}}$ Juliana Pfrimer Falcão

Ribeirão Preto 
I AUTHORIZE THE REPRODUCTION AND TOTAL OR PARTIAL DISCLOSURE OF THIS WORK, BY ANY CONVENTIONAL OR ELECTRONIC MEANS, GIVEN THIS WORK IS PROPERLY REFERENCED

Seribelli, Amanda Aparecida

Analyses of the genomes, transcriptomes and phenotypic characterization of Salmonella Typhimurium strains isolated from humans, food and swine in Brazil, 2021. 176p.: il.; $30 \mathrm{~cm}$.

Doctoral Thesis presented to the Graduation Program of Biosciences and Biotechnology of the School of Pharmaceutical Sciences of Ribeirão Preto/USP for the degree of Doctor in Sciences - Concentration area: Bioagents and Biotechnology Applied to Pharmacy

Supervisor: Falcão, Juliana Pfrimer

1. Salmonella Typhimurium 2. Whole genome sequencing 3. Phenotypic tests related to virulence 4 . Transcriptome 


\section{RESUMO}

SERIBELLI, A. A. Análises dos genomas, transcriptomas e caracterização fenotípica de linhagens de Salmonella Typhimurium isoladas de humanos, alimentos e suínos no Brasil. 2021. 176f. Tese (Doutorado). Faculdade de Ciências Farmacêuticas de Ribeirão Preto - Universidade de São Paulo, Ribeirão Preto, 2021.

Salmonella enterica subsp. enterica sorovariedade Typhimurium ( $S$. Typhimurium) é uma das principais causas de gastroenterite em vários países ao redor do mundo. Ademais, $S$. Typhimurium sequence type (ST) 313 é emergente e tem causado doença invasiva principalmente na África Subsaariana e sua presença foi recentemente descrita no Brasil. Entretanto, no país há poucos estudos que elucidaram possíveis diferenças na diversidade genotípica, expressão gênica e virulência de linhagens de $S$. Typhimurium isoladas de diferentes fontes e pertencentes a importantes STs. Na presente tese, seis importantes questões foram abordadas: (1) Qual é a diversidade de single nucleotide polymorphism (SNP) e de genes de resistência entre linhagens de $S$. Typhimurium isoladas de humanos e alimentos? (2) As linhagens de $S$. Typhimurium ST313 isoladas de humanos e alimentos são geneticamente distintas entre si e em comparação a outros STs? (3) Como linhagens de $S$. Typhimurium isoladas de humanos e alimentos se comportam diante de testes fenotípicos relacionados à virulência? (4) Qual é a diversidade genética de linhagens de $S$. Typhimurium isoladas de suínos? (5) Quais são as diferenças genômicas das linhagens de $S$. Typhimurium isoladas de humanos, alimentos e suínos? (6) Como a linhagem de $S$. Typhimurium ST313 se comporta em um modelo animal clássico e quais são as suas diferenças de expressão gênica em comparação a linhagens do ST19? Foi evidenciado que o resultado filogenético baseado em SNP agrupou as linhagens de $S$. Typhimurium em dois grandes grupos, sugerindo a existência de um subtipo prevalente, provavelmente mais adaptado para as linhagens isoladas de humanos e com alguma diversidade de subtipos para as linhagens de alimentos. A variedade e prevalência de genes de resistência encontrados nessas linhagens de $S$. Typhimurium reforçaram o potencial perigo destas para humanos sob tratamento e o risco da sua presença em alimentos no Brasil. Os genomas de linhagens de S. Typhimurium ST313 do Brasil mostraram grande semelhança entre si, cujas informações podem eventualmente ajudar no desenvolvimento de vacinas e antimicrobianos. A análise do pangenoma mostrou que os genomas de $S$. Typhimurium estudados apresentavam um pangenoma aberto, mas especificamente tendendo a se tornar fechado para as linhagens de $S$. Typhimurium ST313. A capacidade das $S$. Typhimurium estudadas invadirem as células epiteliais Caco-2 foi variável e não está relacionada com a fonte ou o ano de isolamento. Contudo, linhagens de $S$. Typhimurium isoladas de humanos mostraram maiores taxas de sobrevivência em macrófagos humanos U937 e apresentaram maior proporção de isolados com perfil virulento em larvas de G. mellonella quando comparadas com as linhagens isoladas de alimentos, sugerindo que essa diferença pode estar relacionada à maior frequência de isolados humanos que continham genes plasmidiais, tais como operon spvABCDR, operon pefABCD, rck e mig-5. O cgMLST e BLAST Atlas foram mais eficientes na discriminação das linhagens isoladas de suínos estudadas em comparação com o wgMLST. O potencial patogênico dessas linhagens de suínos foi corroborado pela presença de importantes Salmonella pathogenicity islands (SPIs) relacionadas à patogênese de $S$. Typhimurium. As análises filogenéticas agruparam a maioria dos isolados de $S$. Typhimurium de origens diversas em um único grupo, sugerindo a presença de um subtipo prevalente que contaminou com sucesso fontes humanas, alimentares e animais há 30 anos no Brasil. A análise de agrupamentos de proteínas ortólogas revelou genes únicos nas linhagens de $S$. Typhimurium estudadas, principalmente relacionados ao metabolismo bacteriano e que podem ser importantes em sua patogenicidade. Isolados de $S$. Typhimurium 
de suínos apresentaram maior diversidade de STs e profagos em comparação com as linhagens de $S$. Typhimurium isoladas de humanos e alimentos. O potencial patogênico das linhagens de $S$. Typhimurium foi corroborado pela presença de profagos exclusivos dessa sorovariedade envolvidos em sua virulência. O elevado número de genes de resistência relacionados às bombas de efluxo é preocupante e pode levar a falhas terapêuticas quando houver necessidade de tratamento. S. Typhimurium STm30 (ST313) isolada de fezes de humano no Brasil demonstrou maior expressão de genes relacionados à patogênese a $37^{\circ} \mathrm{C}$, além de melhor colonização e invasão no cólon murino, devido aos maiores níveis de expressão de genes de virulência e as citocinas pró-inflamatórias também foram mais expressas nesse órgão, sugerindo maior dano tecidual em comparação com as linhagens de $S$. Typhimurium SL1344 (ST19) e $S$. Typhimurium STm11 (ST19) isoladas de fezes humanas no Brasil. Finalmente, os resultados obtidos contribuíram para uma melhor caracterização da virulência e da diversidade genotípica desse importante enteropatógeno mundial.

Palavras-chave: Salmonella Typhimurium, sequenciamento do genoma completo, testes fenotípicos relacionados à virulência, transcriptoma. 


\begin{abstract}
SERIBELLI, A. A. Analyses of the genomes, transcriptomes and phenotypic characterization of Salmonella Typhimurium strains isolated from humans, food and swine in Brazil. 2021. 176f. Thesis (Doctorate). School of Pharmaceutical Sciences of Ribeirão Preto - University of São Paulo, Ribeirão Preto, 2021.
\end{abstract}

Salmonella enterica subsp. enterica serovar Typhimurium ( $S$. Typhimurium) has been an important cause of gastroenteritis in various countries worldwide. In addition, $S$. Typhimurium sequence type (ST) 313 has been emerging as a cause of invasive disease mainly in sub-Saharan Africa and its presence was recently described in Brazil. However, in Brazil there are few studies that have elucidated possible differences in the genotypic diversity, gene expression and virulence of $S$. Typhimurium strains isolated from different sources and belonging to important STs. In the present thesis, six important questions were addressed: (1) What is the diversity of single nucleotide polymorphism (SNP) and resistance genes among $S$. Typhimurium strains isolated from humans and food? (2) Are genetically distinct the $S$. Typhimurium ST313 strains isolated from humans and food among each other and in comparison to other STs? (3) How do $S$. Typhimurium strains isolated from humans and food behave in phenotypic tests related to virulence? (4) What is the genetic diversity of $S$. Typhimurium strains isolated from swine? (5) What are the genomic differences of $S$. Typhimurium strains isolated from humans, food and swine? (6) How do the $S$. Typhimurium ST313 strain behave in a classic animal model and what are their differences in gene expression in comparison to ST19 strains? Phylogenetic results placed the S. Typhimurium strains into two major clades suggesting the existence of a prevalent subtype, likely more adapted, among strains isolated from humans, with some diversity in subtypes in isolates from food. The variety and prevalence of resistant genes found in these Salmonella Typhimurium strains reinforced their potential hazard for humans under treatment and the risk of its presence in foods in Brazil. The ST313 genomes from Brazil showed a high similarity among them which information might eventually help in the development of vaccines and antibiotics. The pangenome analysis showed that the $S$. Typhimurium genomes studied presented an open pangenome, but specifically tending to become closed for the ST313 strains. The ability of the studied $S$. Typhimurium to invade Caco-2 epithelial cells was strain dependent and was not related to the source or the year of isolation. However, $S$. Typhimurium strains isolated from humans showed greater survival rates in U937 human macrophages and presented higher proportion of isolates with a virulent related profile in G. mellonella larvae in comparison to strains isolated from food suggesting that this difference may be related to the higher frequency of human isolates which contained plasmidial genes, such as $s p v A B C D R$ operon, pefABCD operon, $r c k$ and mig-5. The cgMLST and BLAST Atlas were more efficient at discriminating the swine isolates studied in comparison to wgMLST. The pathogenic potential of the swine strains studied was corroborated by the presence of important Salmonella pathogenicity islands (SPIs) related to the pathogenesis of $S$. Typhimurium. Phylogenetic analyses grouped the majority of the $S$. Typhimurium strains of diverse origins into a single cluster suggesting that there was one prevalent subtype that has successful contaminated human, food and animal sources for 30 years in Brazil. The orthologous protein clusters analysis revealed unique genes in the $S$. Typhimurium studied mainly related to bacterial metabolism and that may be important in their pathogenicity. $S$. Typhimurium isolates from swine showed greater diversity of STs and prophages in comparison to $S$. Typhimurium strains isolated from humans and foods. The pathogenic potential of $S$. Typhimurium strains was corroborated by the presence of exclusive prophages of this serovar involved in its virulence. The high number of resistance genes related to efflux pumps is worrying and may 
lead to therapeutic failures when treatment is needed. $S$. Typhimurium STm30 (ST313) isolated from human feces in Brazil demonstrated greater expression of genes related to pathogenesis at $37^{\circ} \mathrm{C}$, besides better colonization and invasion in the murine colon due to higher levels of expression of virulence genes and pro-inflammatory cytokines were also more expressed in this organ, suggesting greater tissue damage in comparison to $S$. Typhimurium SL1344 (ST19) and S. Typhimurium STm11 (ST19) isolated from human feces in Brazil. Finally, the results obtained contributed for a better characterization of the virulence and genotypic diversity of this important enteropathogen worldwide.

Keywords: Salmonella Typhimurium, whole genome sequencing, phenotypic tests related to virulence, transcriptome. 


\section{1 - INTRODUCTION}

\subsection{Salmonella genus}

The Salmonella genus was identified by an American scientist named Dr. Daniel E. Salmon in 1885, since then numerous advances in the understanding of this bacterium and salmonellosis disease have been revealed, including the identification of the two main Salmonella pathogenicity islands (SPIs) denominated SPI-1 and SPI-2 which are essential for Salmonella invasion and survival in the host cells (PETERSEN and MILLER, 2019).

Salmonella genus belongs to the Enterobacteriaceae family and consists of at least 2500 serovars, which approximately $80-90$ of these serovars have been of considerable importance to the health of humans and animals. Besides, it is a Gram-negative bacilli, nonspore-forming and strains are usually not capable to ferment lactose, but some Salmonella strains can ferment this carbohydrate due to the acquisition of plasmids (lac + ) (FERREIRA and CAMPOS, 2008; CARVALHO et al., 2016). Furthermore, this bacterium has the ability to ferment arabinose, maltose, mannitol, mannose, rhamnose, sorbitol, trehalose, xylose and dulcitol, perform decarboxylation of the amino acids lysine and ornithine, reduction of nitrate to nitrite and utilization of citrate as the sole carbon source (BRAZIL, 2011).

In addition, the classification and identification nomenclature of Salmonella are complex and different researchers use distinct systems to reference this genus. Currently, the most accepted approach has been that the genus is divided into two major species: Salmonella enterica and Salmonella bongori (ISSENHUTH-JEANJEAN et al., 2014). According to the Wang and collaborators (2019), S. bongori has been successful in infecting cold-blooded hosts, but there are some reports of this bacterium infecting warm-blooded animals (WANG et al., 2019a).

Salmonella enterica is divided into six subspecies with thousands of serovars: $S$. enterica subspecies enterica, S. enterica subspecies salamae, S. enterica subspecies arizonae, S. enterica subspecies diarizonae, S. enterica subspecies houtenae and S. enterica subspecies indica (BRENNER et al., 2000; ISSENHUTH-JEANJEAN et al., 2014).

Salmonella serovars have been usually identified using the White-Kauffmann-Le Minor (WKL) scheme since 1930 and this identification is based on the serology of the O (somatic), H (flagellar) and capsular (Vi - may not be present) antigens (BRENNER et al., 2000; FERREIRA and CAMPOS, 2008; NATARO et al., 2011; YOSHIDA et al., 2016).

Moreover, Salmonella enterica subspecies enterica can also be divided into two major groups: typhoidal and non-typhoidal, which have been associated with distinct diseases 
(NATARO et al., 2011). Typhoid and paratyphoid fever are caused by the $S$. Typhi and $S$. Paratyphi serovars, respectively and the infection initially develops in the intestinal mucosa progressing to a systemic disease (FERREIRA and CAMPOS, 2008). The multiplication of the bacteria occurs in the spleen and liver of the host, causing bacteremia and the development of high fever, headache, poor appetite, abnormal heart rhythm, increase in spleen volume, diarrhea, among others (FERREIRA and CAMPOS, 2008).

Non-typhoidal Salmonella (NTS) has been an important cause of gastroenteritis worldwide (HOHMANN, 2001; EUROPEAN CENTRE FOR DISEASE PREVENTION AND CONTROL (ECDC), 2014; SERIBELLI et al., 2020; CENTERS FOR DISEASE FOR CONTROL AND PREVENTION (CDC), 2021). According to Majowicz and collaborators (2010), it was estimated that globally occur 93.8 million cases and approximately 155,000 deaths due to NTS every year in which 80.3 million cases have been transmitted by the ingestion of contaminated foods.

In Brazil, Salmonella has been one of the most common causes of foodborne outbreaks during the last decade and animal products have been the main vehicle for the transmission of this disease (BRAZIL, 2010; BRAZIL, 2019).

Salmonella transmission occurs mainly due to the ingestion of contaminated water and/or food, such as eggs, meat, poultry, milk and vegetables (WORLD HEALTH ORGANIZATION (WHO), 2018). Furthermore, there are other possibilities of contamination including person-to-person contact via fecal-oral route and contact with pets since these animals often do not show signs or symptoms of salmonellosis (WHO, 2018). It is important to mention that Salmonella is resistant to unfavorable environmental factors and it can proliferate in temperatures ranging from $35^{\circ} \mathrm{C}$ to $43^{\circ} \mathrm{C}$ with the extremes tolerated of $5^{\circ} \mathrm{C}$ and $46^{\circ} \mathrm{C}$, as well as growth in $\mathrm{pH} 7.0$ and 7.5 with the tolerated extremes of 3.8 and 9.5 (BRAZIL, 2011).

In addition, gastroenteritis caused by Salmonella is usually a self-limited disease which the symptoms disappear after four to seven days and there is no need of treatment with antimicrobials (CDC, 2019a). The main symptoms resulting from salmonellosis are diarrhea, fever and stomach cramps that have been predominantly caused by the $S$. Enteritidis and $S$. Typhimurium serovars in many countries worldwide (SCHULTE and HENSE, 2016; ARYA et al., 2017). However, systemic infections can occur in children and immunocompromised patients (SCHULTE and HENSE, 2016; ARYA et al., 2017). Specifically, it is known that children under 5 years old, infants, adults over 65 years and people who have other coexisting 
diseases or use drugs that act by lowering the immune defense are more likely to develop severe disease due to Salmonella (CDC, 2019a).

Furthermore, a recent literature review indicated that nine cases of more serious complications from NTS infection in pregnant women were reported between 1966 and 2018 (MOLLO et al., 2019). The main complications were sepsis, spontaneous abortions and fatal outcomes, emphasizing that even in a small proportion of cases this bacterium can cause severe conditions in pregnant women (MOLLO et al., 2019).

It is important to mention that many NTS serovars have been described as host generalist, such as $S$. Typhimurium and $S$. Enteritidis, which are capable of infecting animals and humans. On the other hand, there are serovars host adapted, such as S. Gallinarum in poultry, $S$. Dublin in cattle and $S$. Choleraesuis in pigs (ARYA et al., 2017; WHO, 2018; CDC, 2021).

According to Fernandes and collaborators (2006), S. Typhimurium was the second most prevalent serovar in São Paulo State between 1996 and 2003. Similarly, in Pará State, S. Typhimurium was also the second most isolated serovar from outbreaks and sporadic cases of diarrhea during 2010 to 2013 (ASSIS et al., 2017). In addition, in Rio de Janeiro State, 129 isolates of Salmonella were identified between 2009 and 2013 with $S$. Typhimurium being the most frequent (48.8\%) serovar among the isolates (PRIBUL et al., 2017).

Moreover, among the thousands NTS serovars it is estimated that globally the $S$. Typhimurium and $S$. Enteritidis serovars represent $50 \%$ of all isolates reported from humans with salmonellosis (ARYA et al., 2017). Specifically, S. Typhimurium has been the second most isolated serovar of salmonellosis cases between 2013-2014 in important countries including Canada, United States and European Union (EU) (ARYA et al., 2017).

Currently, the world has been under the threat of antimicrobial resistant pathogens affecting public health, food development and the environment (WHO, 2020). According to the National Antimicrobial Resistance Monitoring System for Enteric Bacteria (NARMS) (2020), the indiscriminate use of antimicrobials in humans and animals selects resistant bacteria, making treatment difficult when necessary. Increasing numbers of diseases caused by antimicrobial resistant bacteria, such as tuberculosis, gonorrhea and salmonellosis has been observed (WHO, 2020).

In the EU, the latest data in 2017/2018 indicated that there was an increase in the number of Salmonella multidrug resistant (MDR) isolates (resistant to three or more antimicrobials classes) from humans, animals and food (ECDC, 2020). Salmonella strains 
isolated from humans resistant to ciprofloxacin had a significant increase, being this drug an important antibiotic used for the treatment of salmonellosis when necessary (ECDC, 2020).

In the United States, drug resistant NTS has been a serious threat to public health and causes more than 212,000 infections and 70 deaths every year (CDC, 2019b). Furthermore, in 2017, ciprofloxacin resistant NTS caused approximately 89,200 infections in this country, remembering that usually antibiotics such as ciprofloxacin, azithromycin and ceftriaxone may be needed for treatment of this disease (CDC, 2019b).

It is important to emphasize that the antimicrobial resistance in $S$. Typhimurium strains has also increased in the last year in many countries (WANG et al., 2019b). Data from CDC and NARMS between 1996 and 2016 showed that it was possible to observe that the most frequently reported resistance in this serovar isolated from food chain was ampicillin, chloramphenicol, streptomycin, sulfonamides and tetracycline (WANG et al., 2019b). In addition, the presence of ceftriaxone resistant $S$. Typhimurium strains was also reported in animals, meat and humans, causing concern for being a treatment option in severe cases as mentioned before (WANG et al., 2019b).

Therefore, this problem is so serious that there is an estimate that infections caused by antimicrobial resistant pathogens if the control measures fail will kill approximately 10 million people in all the world in 2050, thus over coming other diseases, such as cancer, cholera, diabetes, diarrhoeal disease, measles and tetanus (O’ NEILL, 2014).

\subsection{Salmonella Typhimurium}

As mentioned earlier $S$. Typhimurium is a generalist serovar and can infect humans, cattle, pigs, sheep, horses, rodents, turtles, chickens, turkeys, ducks, pigeons and birds (RABSCH et al., 2002; WORK et al., 2019). The detection of $S$. Typhimurium in poultry and pigs is difficult due to the different outcomes of the bacteria in these animals, including asymptomatic cases, diarrhea or more severe cases causing deaths (BEST et al., 2007; ÖSTERBERG; LEWERIN; WALLGREN, 2010; DAR et al., 2017). Usually, such animals show no symptoms and can transmit the bacteria to humans through consumption and handling of their contaminated meat (BEST et al., 2007; ÖSTERBERG; LEWERIN; WALLGREN, 2010; DAR et al., 2017).

$S$. Typhimurium has been isolated mainly from humans and animals, including poultry and pigs (EVANGELOPOULOU et al., 2015; PORTER et al., 2019). According to Porter and collaborators (2019), S. Typhimurium was the main serovar isolated from pigs in Northern 
Ireland between 1997 and 2016. Furthermore, this serovar has been the causative agent of several outbreaks associated with consumption of pork in the EU in recent years demonstrating its importance in pig's production (CAMPOS et al., 2019).

In Brazil, it is also possible to observe that $S$. Typhimurium has been isolated from the intestinal content of pigs, carcasses and surrounding pig environment, which can represent risk of contamination in all meat production processes (ALMEIDA et al., 2016a; PAIM et al., 2019). According to the Brazilian Association of Animal Protein (ABPA), Brazil has been ranked as the fourth largest producer of pig meat, surpassed only by China, EU and the United States, producing 3,983 thousand tons of pig meat and exporting 750 thousand tons in 2019 (ABPA, 2020).

Control and prevention measures have been of great importance in relation to $S$. Typhimurium contamination in pigs (RODRÍGUEZ and SUÁREZ, 2014). This contamination can occur during the different stages of pork production, including transport, carcass processing and meat handling and storage, generating damage for producers and consumers (RODRÍGUEZ and SUÁREZ, 2014; EVANGELOPOULOU et al., 2015). In addition, research should be encouraged mainly in pork producing and exporting countries such as Brazil due to the emergence of this pathogen related to the political, economic, and public health sectors (RODRÍGUEZ and SUÁREZ, 2014; EVANGELOPOULOU et al., 2015).

It is known that Invasive Non-typhoidal Salmonella (iNTS) has been a serious public health problem frequently reported in the African continent and mainly related to other diseases, such as acquired human immunodeficiency virus infection (HIV), malaria, malnutrition, cachexia, and sickle cell anemia (SINGLETARY et al., 2016; GILCHRIST and MACLENNAN, 2019).

According to Ao et al. (2015), it was estimated that occur annually 3.4 million cases and more than 680 thousand deaths due to iNTS worldwide, which the African continent has been the most affected with 227 cases per 100,000 populations. Unfortunately, in Ghana the estimated incidence was 2,520 cases of iNTS per 100,000 population between 2007 to 2009 in children under 5 years old (UCHE; MACLENNAN; SAUL, 2017).

It is important to emphasize that iNTS has been the most isolated agent in Africa, which has a mortality rate around 18 to 25\% (REDDY; SHAW; CRUMP, 2010; FEASEY et al., 2012; GILCHRIST and MACLENNAN, 2019). Therefore, bloodstream infections have been frequently reported with high mortality rates, indicating the need for preventive and control measures mainly in this continent (REDDY; SHAW; CRUMP, 2010). 
Specifically, a summary of 22 studies resulting from bloodstream infections in Africa between 1984-2006 indicated that in North Africa the prevalence was of the $S$. Typhi serovar in adults (REDDY; SHAW; CRUMP, 2010). During this period, in West and Central Africa, NTS was the predominant agent from bloodstream infections in children (REDDY; SHAW; CRUMP, 2010). In East Africa, NTS was the second most prevalent agent from bloodstream infections in children and adults (REDDY; SHAW; CRUMP, 2010). Finally, in Southern Africa, NTS was the most isolated agent from bloodstream infections in children and adults (REDDY; SHAW; CRUMP, 2010).

Among NTS serovars that have been successful in causing invasive disease in young age and adults with other underlying health conditions it should be highlighted the $S$. Enteritidis, $S$. Typhimurium and $S$. Dublin serovars (BALASUBRAMANIAN et al., 2019). According to Reddy and collaborators (2010), S. Typhimurium was the most isolated serovar $(65.2 \%)$ in the African continent from bloodstream infections in children and adults. Specifically, there is an epidemic invasive disease mainly in sub-Saharan Africa caused by $S$. Typhimurium belonging to the sequence type (ST) 313 (BALASUBRAMANIAN et al., 2019).

The ST is obtained by the Multilocus sequence typing (MLST) technique and $S$. Typhimurium ST313 was characterized as being genetically distinct from $S$. Typhimurium ST19 which has been reported as the most frequent ST in strains of this serovar (FEASEY et al., 2012; FEASEY et al., 2014; KARIUKI and ONSARE, 2015). Clinical and epidemiological data indicated that $S$. Typhimurium ST313 has been closely linked to invasive systemic disease, such as bacteremia, septicemia and meningitis in Africa (RAMACHANDRAN et al., 2015). On the other hand, cases of gastroenteritis have been predominantly caused by $S$. Typhimurium ST19 in different parts of the globe (RAMACHANDRAN et al., 2015).

It is known that $S$. Typhimurium ST313 and $S$. Typhimurium ST19 present differences in their behavior during infection; but there are few studies that tried to elucidate such differences mainly in vivo (OKORO et al., 2015; YANG et al., 2015a; RAMACHANDRAN et al., 2015; RAMACHANDRAN et al., 2017). In addition, the presence of $S$. Typhimurium ST313 strains have been recently described in Brazil (ALMEIDA et al., 2017a; PANZENHAGEN et al., 2018). According to Almeida and collaborators (2017a), the ST19 was the most frequently reported in $88 \mathrm{~S}$. Typhimurium strains isolated from humans and food in Brazil and the ST313 was the second most reported. 
According to Pulford and collaborators (2020), S. Typhimurium ST313 strains may be successful in causing invasive disease in Africa due to resistance to antimicrobials and lossof-function in genes that are not needed for systemic infection. Furthermore, these authors found a variant of ST313 denominated L3 that emerged in Malawi in 2016, which was pan susceptible and clonally related to ST313 strains isolated predominantly from cases of gastroenteritis found in the UK and Brazil (ALMEIDA et al., 2017a; PULFORD et al., 2020).

\subsection{Virulence}

The infection by $S$. Typhimurium strains begins in the fecal oral route through ingestion of contaminated water and/or food (GILCHRIST; MACLENNAN; HILL, 2015). S. Typhimurium has the ability to invade, survive and replicate within host cells due to the Type III Secretion Systems (T3SS-1 and T3SS-2) which are encoded by genes located in Salmonella pathogenicity islands 1 and 2 (SPIs) denominated SPI-1 and SPI-2, respectively (KIMBROUGH and MILLER, 2002; HURLEY et al., 2014; SANTOS; FERRARI; CONTEJUNIOR, 2019).

Overall, the $\operatorname{sip} A, \operatorname{sip} B, \operatorname{sip} C, \operatorname{sip} D, \operatorname{sop} E, \operatorname{sop} E 2, \operatorname{sop} B, \operatorname{sop} D$ and $\operatorname{sop} A$ genes are SPI-1 effectors and decisive for the entry of $S$. Typhimurium in the host cells (IBARRA and STEELE-MORTIMER, 2009; HEIJDEN and FINLAY, 2012; HURLEY et al., 2014). Specifically, the T3SS-1 is basically formed by a needle complex, export apparatus and translocon, which is known as molecular syringe, because its activation triggers signaling cascades that manipulate the host cells and generate disarrangements (IBARRA and STEELEMORTIMER, 2009; JONG et al., 2012; SANTOS; FERRARI; CONTE-JUNIOR, 2019).

In addition, $S$. Typhimurium can alternatively be taken to the intestinal submucosa without invading due to internalization by dendritic cells or $\mathrm{M}$ cell mediated transcytosis (SANTOS; FERRARI; CONTE-JUNIOR, 2019; WEMYSS and PEARSON, 2019). The induction and regulation of the T3SS-1 occurs in environments with changes in the osmolarity, density, $\mathrm{pH}$ and aeration, the hilA gene is the main transcriptional activator of the SPI-1 effectors (HEIJDEN and FINLAY, 2012).

Once $S$. Typhimurium is already internalized, the SPI-1 effectors induce development of a vacuole denominated Salmonella-containing vacuole (SCV) and become downregulated (WEMYSS and PEARSON, 2019). While, the SPI-2 effectors become upregulated (T3SS-2), such as the pipB2, sopD2, sifA, sspH2, steC, sseF, sseG, sseI and sseJ genes that are mainly responsible by the SCV maturation and intracellular survival of $S$. Typhimurium inside of 
intestinal epithelial cells or phagocytic cells as in local intestinal macrophages (HEIJDEN and FINLAY, 2012; HURLEY et al., 2014; WEMYSS and PEARSON, 2019).

It is important to mention that after $S$. Typhimurium have crossed the epithelial barrier, local macrophages engulf the bacteria trying to control the infection, but $S$. Typhimurium is capable to escape of these cells, because the expression of SPI-2 effectors (T3SS-2) prevent the fusion of the SCV with the lysosome, causing apoptosis of the local macrophages (HEIJDEN and FINLAY, 2012; HURLEY et al., 2014; WEMYSS and PEARSON, 2019). The induction and regulation of the T3SS-2 occurs after the production of the SCV and the SsrB transcriptional regulator is capable to connect and activate all SPI-2 effectors (HEIJDEN and FINLAY, 2012).

Salmonellosis can be summarized in some topics, including adhesion and invasion to intestinal epithelial cells (T3SS-1), survival and proliferation in host cells, such as intestinal epithelial cells and macrophages (SCV - T3SS-2), recruitment of more phagocytic cells to the infection site and intestinal homeostasis imbalance, triggering fluid and electrolyte loss through diarrhea (Fig. 1) (GILCHRIST; MACLENNAN; HILL, 2015; SANTOS; FERRARI; CONTE-JUNIOR, 2019). 
Fig. 1 - Pathogenesis of Salmonella Typhimurium

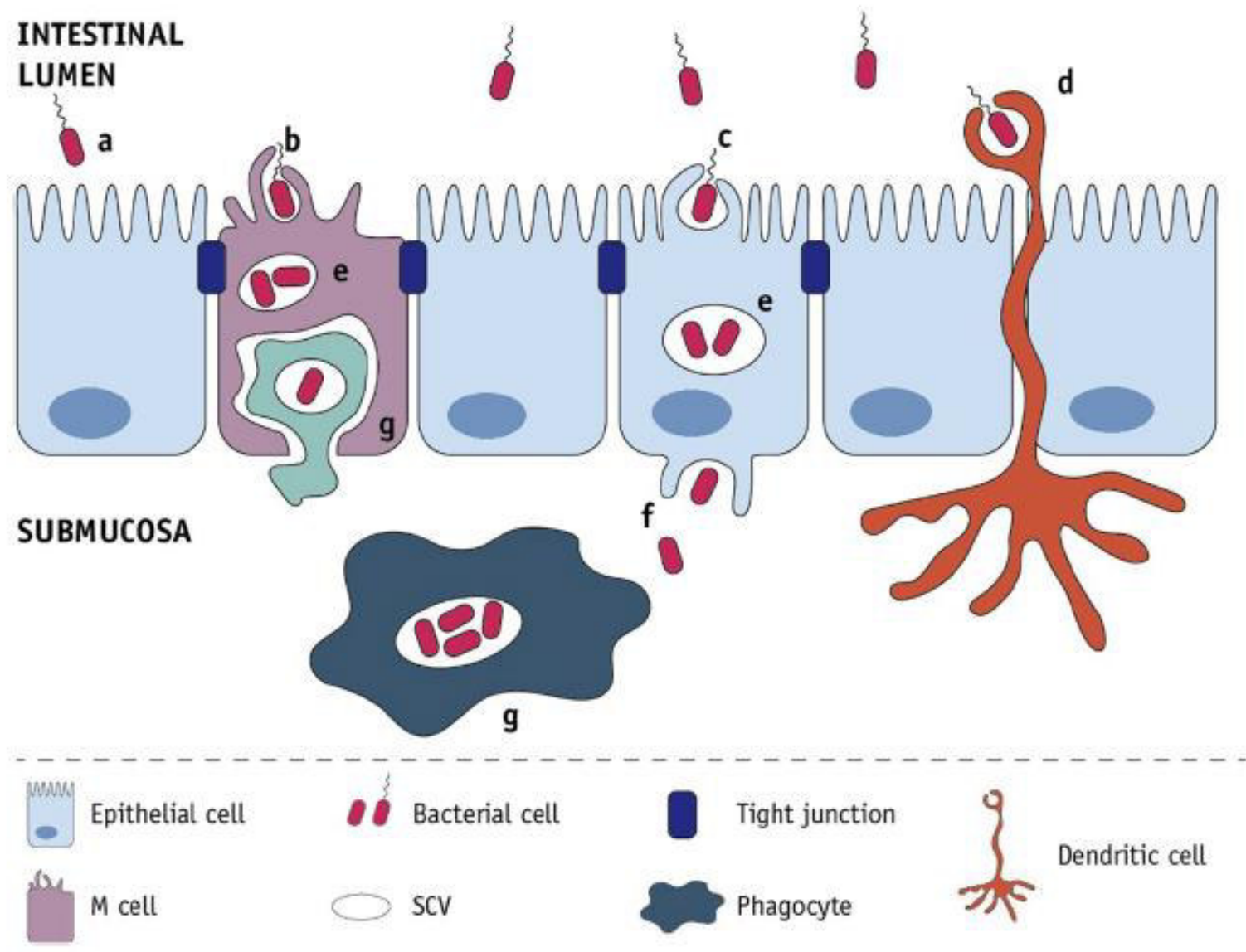

Source: Santos; Ferrari; Conte-Junior, Current Microbiology, 2019.

a Salmonella adheres to the intestinal epithelial and M cells using many of adhesion factors present on its cell surface. b, $\mathbf{c}$ Effector proteins are released into enterocyte causing changes on its cytoskeleton and forming structures in its surface known as ruffles. d Alternatively, the bacterial cells can be directly taken by dendritic cell from the submucosa. e Once inside cytoplasm, Salmonella cells are located into SCV (Salmonella-containing Vacuoles), where it multiplies. f The SCV transcytose to the basolateral membrane and release to the submucosa. g Bacteria is internalized within phagocytes and then located again into SCV; this figure was based on the one illustrated in the article Sansonetti, Gut, 2002.

It is known that the invasive disease mainly caused in children by $S$. Typhimurium ST313 in sub-Saharan Africa presents in addition to the pathogenesis mentioned above, systemic dissemination through the bloodstream and establishment of new infectious sites culminating in cough, dyspnea, convulsions, tachycardia, tachypnea, respiratory distress, hepatomegaly, and splenomegaly (MACLENNAN et al., 2017; GILCHRIST and MACLENNAN, 2019).

According to Gilchrist and Maclennan (2019), it is not clear why the $S$. Typhimurium ST313 strains are being more invasive; but there are some phenotypes that may contribute to these cases, such as degradation of the complement system on the bacterial surface, reduction 
in colitis and recruitment of neutrophils, resistance to death serum and attenuated inflammatory response in macrophages (GILCHRIST and MACLENNAN, 2019).

The virulence plasmid (pSLT) has been reported in $S$. Typhimurium and carries important genes for the pathogenesis of this serovar. Specifically, in this plasmid there is a highly conserved region denominated $s p v$ (Salmonella plasmid virulence) which encodes four structural genes $s p v A, s p v B, s p v C$ and $s p v D$ and the regulatory gene $s p v R$ (GUINEY et al., 1995; GILCHRIST and MACLENNAN, 2019).

In addition, the $s p v B$ and $s p v C$ genes are T3SS-2 effectors, participating in the processes of host macrophages apoptosis and decreasing the inflammatory response, respectively (IBARRA and STEELE-MORTIMER, 2009; HEIJDEN and FINLAY, 2012).

Bacteriophages or phages are virus specialized in infecting bacteria and can perform the lytic and/or lysogenic cycles in the host cells (KROPINSKI, 2009; SWITT et al., 2015). In the lytic cycle, the virus "hijacks" the host cell machinery, giving rise to thousands of descending virus and leading the cell to death. On the other hand, in the lysogenic cycle, the virus integrates its DNA with bacterial DNA denominated prophage (SWITT et al., 2015). Prophages can be related to several functions in bacterial cells, such as virulence, metabolism, signaling, evolution and ecology (WAHL; BATTESTI; ANSALDI, 2019).

The Gifsy prophages carry genes that favor the virulence of $S$. Typhimurium in the host cells (KLUMPP and FUCHS, 2007; NGOI; YAP; THONG, 2018). Specifically, the Gifsy-1 and Gifsy-2 prophages encode genes involved in the intracellular survival of Salmonella in the host cells (FIGUEROA-BOSSI and BOSSI, 1999; WAHL; BATTESTI; ANSALDI, 2019).

It is important to mention that the Gifsy prophages are found only in $S$. Typhimurium, as well as the Fels-1 and Fels-2 prophages (NGOI; YAP; THONG, 2018). According to Brüssow, Canchaya and Hardt (2004), the Fels-1 and Fels-2 prophages encode genes related to adherence and survival of $S$. Typhimurium to host cells (WAHL; BATTESTI; ANSALDI, 2019).

Furthermore, it was described that the $S$. Typhimurium LT2 reference strain presented the Gifsy-1, Gifsy-2, Fels-1 and Fels-2 prophages and these prophages have been described in $S$. Typhimurium isolated in other countries including Australia, Europe and China (GARCÍA et al., 2013; PANG et al., 2013; YANG et al., 2015b; NGOI; YAP; THONG, 2018). 


\subsection{Immune response}

Innate immunity is the first line of defense against pathogens, which is capable to induce a series of cellular and inflammatory responses that try to block the infection (BROZ; OHLSON; MONACK, 2012). It is known that $S$. Typhimurium causes severe intestinal inflammation due to its invasion into host cells (BROZ; OHLSON; MONACK, 2012). This bacterium is adapted to survive and multiply in this inflammatory environment, as well as uses this adaptation to benefit from other microorganisms found in the intestinal microbiota (BROZ; OHLSON; MONACK, 2012).

In the moment that $S$. Typhimurium reaches its target organ pattern recognition receptors (Toll-like) that detect the presence of the invading pathogen extracellularly and stimulate the release of pro-inflammatory cytokines, such as IL-23 (BROZ; OHLSON; MONACK, 2012; HURLEY et al., 2014). During the course of the infection, S. Typhimurium invades host cells promoting the release of different cytokines, including the interleukins IL$1 \beta$, IL-18, IL-6, interferons (IFN- $\gamma$ ) and tumor necrosis factor (TNF- $\alpha$ ), which in general increase the systemic inflammatory response (Fig. 2) (BROZ; OHLSON; MONACK, 2012; HURLEY et al., 2014).

In addition, the interleukin IL-23 promotes the release of interleukins IL-17 and IL-22 that contribute to healing, secretion of antimicrobial molecules and induction of proinflammatory mediators, with consequent recruitment of neutrophils (BROZ; OHLSON; MONACK, 2012; VALERI and RAFFATELLU, 2016). Specifically, the interleukin IL-17 induces other pro-inflammatory cytokines and IL-22 is capable to induce tissue protection (BROZ; OHLSON; MONACK, 2012; VALERI and RAFFATELLU, 2016).

The greater recruitment of neutrophils to the infection site aims to eliminate $S$. Typhimurium strains that are still extracellularly and this cellular and inflammatory flow culminate in damage and disarrangement of the intestinal epithelium, losing the epithelial cell barrier with consequent elimination of fluids through diarrhea (BROZ; OHLSON; MONACK, 2012).

Finally, the immune response triggers a series of cellular and humoral inductions that try to control salmonellosis, among the different cytokines important for these processes it is highlighted the interleukins IL-12 and IL-10 (SALAZAR et al., 2017; ELSNER and SHLOMCHIK, 2019). The interleukin IL-12 is produced mainly by dendritic cells and phagocytes, which plays a key role in stimulating the Th1 response (cell-mediated immune response) (ELSNER and SHLOMCHIK, 2019). According to Salazar and collaborators 
(2017), the interleukin IL-10 is classified as anti-inflammatory which is extremely important to limit the inflammation that occurs during the infectious process and prevent tissue damage, inhibiting other interleukins including IL-12 and IFN- $\gamma$.

Fig. 2 - Schematic illustration of the infection of epithelial cells of the lower intestine and macrophages by Salmonella

A
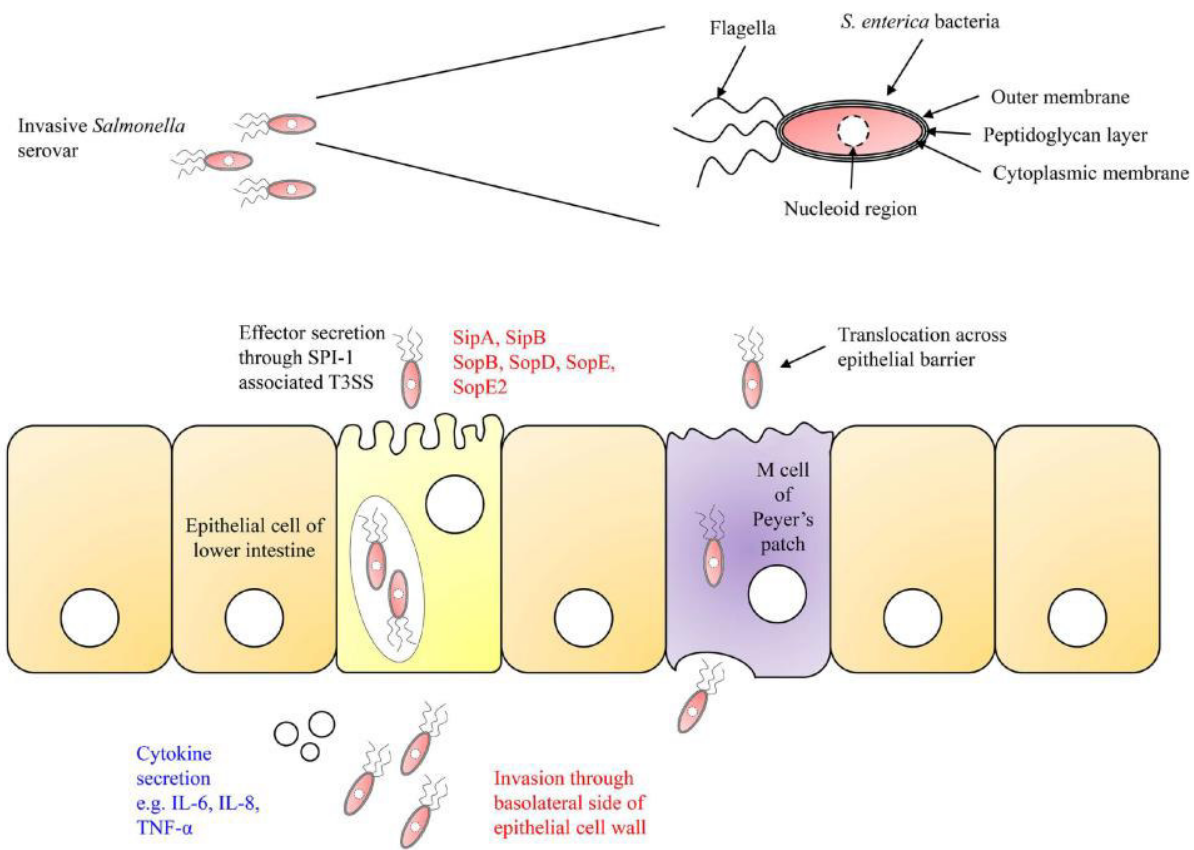

C
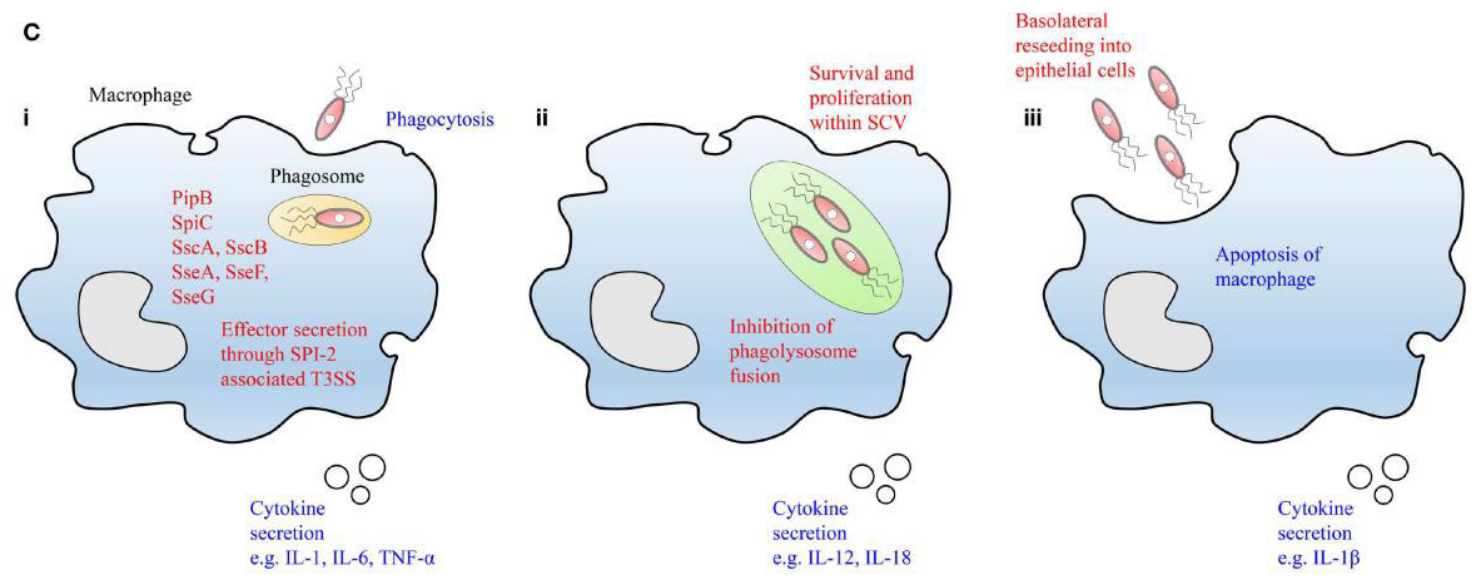

Source: Hurley and collaborators, Frontiers in Immunology, 2014.

(A) The complex membrane structure of Salmonella allows it to survive until reaching the epithelial cell wall of the host in the lower intestine. (B) Salmonella then translocates across M cells of Peyer's patches or actively invade epithelial cells by the secretion of effector proteins through the SPI-1 encoded T3SS-1. (C) (i) After crossing the epithelial barrier, Salmonella is engulfed by proximal macrophages that will secrete effector proteins into the cytosol of the cell via the SPI-2 encoded T3SS-2 and prevent fusion of the phagosome with 
the lysosome. (ii) Within the SCV, Salmonella will proliferate resulting in cytokines secretion by the macrophage. (iii) Finally, the macrophage will undergo apoptosis, and Salmonella will escape the cell basolaterally reinvading epithelial cells or other phagocytic cells of the host innate immune system.

\subsection{Whole genome sequencing (WGS) and RNA-seq}

Over the past 56 years, researchers around the world have witnessed the advent of new-generation sequencing (NGS) for genetic material of prokaryotic and eukaryotic cells (HEATHER and CHAIN, 2016; ILLUMINA, 2021). Specifically, there are currently numerous possibilities for microbial whole genome sequencing (WGS) and RNA-seq in order to better understand its pathogenicity, virulence and epidemiology (ILLUMINA, 2021).

The first step towards the currently available technology was taken in 1965 by Holley and collaborators who sequenced the alanine tRNA from the yeast Saccharomyces cerevisiae. At the same time, Sanger and collaborators developed the sequencing of radiolabeled DNA fragments (HOLLEY et al., 1965; SANGER; BROWNLEE; BARRELL, 1965; HEATHER and CHAIN, 2016).

Currently, the WGS of bacterial strains generates several data that can provide important information for molecular epidemiology, such as genetic similarity among strains from different sources, years and countries, besides the technique allows the detection of virulence and resistance genes and prediction of prophages regions (SHIVANI et al., 2015; CDC, 2016). According to Centers for Disease Control and Prevention (2016), the WGS has been an essential tool for faster diagnoses and extremely useful for the solution or prevention of foodborne epidemics, facilitating work in the areas of health and epidemiological surveillance (CDC, 2016).

In addition, it is important to emphasize that these thousands of data can be analyzed by professionals trained in the area of bioinformatics, since specific softwares must be used for different analyzes, including important concepts for understanding the process of genetic material sequencing (Fig. 3) (FERREIRA and BORGES NETO, 2003, ILLUMINA, 2021). It worth mentioning that this technology allows us to differentiate extremely genetically related strains, as well as provides a refined analysis that differentiates strains at the level of single nucleotide polymorphism (SNPs) (FERREIRA and BORGES NETO, 2003; SHIVANI et al., 2015). Furthermore, the WGS is becoming more affordable because the costs are getting lower and facilities are spread around the world allowing partnership between universities and laboratories (SHIVANI et al., 2015; HEATHER and CHAIN, 2016; ILLUMINA, 2021). 
Transcriptional analyses through RNAseq of Salmonella in different conditions have been useful for understanding the pathogenicity of this important foodborne pathogen (GRUZDEV et al., 2012). It is important to mention that transcriptome studies have provided relevant information on the pathogenicity and virulence of different bacteria, since through this technology it is possible to identify genes involved in different bacterial biological processes, also providing insights about the functions of genes that have not been characterized and indicating possible changes in the proteome and metabolome (CROUCHER et al., 2009; LI et al., 2017; OSHOTA et al., 2017).

Fig. 3 - Workflow of Next-Generation Sequencing (NGS)

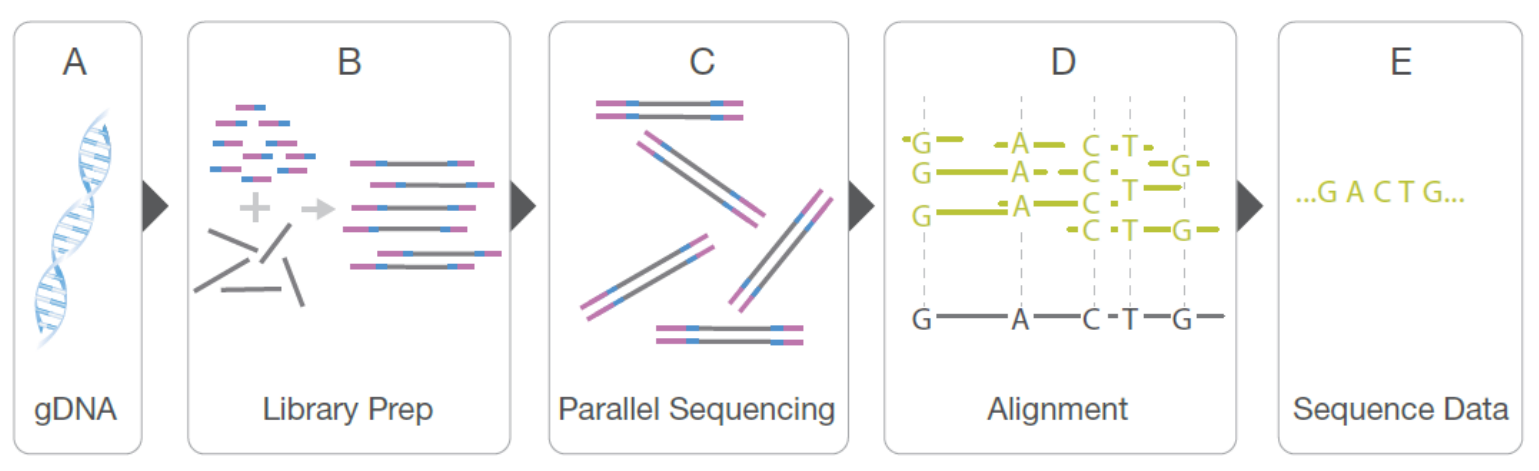

Source: Illumina, 2021.

(A) Extracted genomic DNA. (B) Sample preparation fragments genomic DNA and adds adapters to generate a library. (C) DNA fragments within the library are each sequenced in parallel. (D) Individual sequence reads are reassembled by aligning to a reference genome. (E) The whole genome sequencing is derived from the consensus of aligned reads.

Finally, in Brazil, there are few studies that have characterized possible differences in the genomes, gene expression and virulence of $S$. Typhimurium strains isolated from different sources, belonging to distinct STs and geographic regions in this country. Therefore, studies using WGS analyses, invasion and survival assays, transcriptome and in vivo tests of $S$. Typhimurium strains isolated from humans, food and swine in Brazil are of great importance and should contribute for a better understanding of the genotypic diversity, gene expression and virulence of this important global enteropathogen. 


\section{4- CONCLUSIONS}

- Phylogenetic results placed the studied S. Typhimurium strains from humans and foods into two major clades suggesting the existence of a prevalent subtype, likely more adapted, among strains isolated from humans, with some diversity in subtypes in strains from foods;

- The variety and prevalence of resistant genes found in the Salmonella Typhimurium isolated from humans and foods studied reinforced their potential hazard for humans under treatment and the risk of its presence in foods in Brazil;

- The ST313 genomes from analysed Brazil showed a high similarity among them which information might eventually help in the development of vaccines and antimicrobials;

- The pangenome analysis showed that the selected S. Typhimurium genomes presented an open pangenome, but specifically tending to become closed for the ST313 strains studied;

- The ability of the studied $S$. Typhimurium isolated from humans and foods to invade Caco-2 epithelial cells was strain dependent and was not related to the source or year of isolation;

- S. Typhimurium strains isolated from humans showed greater survival rates in U937 human macrophages, and presented higher proportion of isolates with a virulent profile in $G$. mellonella in comparison to strains isolated from food suggesting that this difference may be related to the higher frequency of human isolates which contained plasmidial genes, such as spvABCDR operon, pefABCD operon, $r c k$ and mig-5;

- The cgMLST and BLAST Atlas were more efficient at discriminating $S$. Typhimurium strains isolated from swine in Brazil in comparison to wgMLST, suggesting greater genetic diversity among these isolates;

- The pathogenic potential of the strains isolated from swine studied was corroborated by the presence of important SPIs related to the pathogenesis of $S$. Typhimurium;

- Phylogenetic analyses grouped the majority of the $S$. Typhimurium strains from diverse origins into a single cluster suggesting that there was one prevalent subtype that has successful contaminated human, food and animal sources for 30 years in Brazil;

- The orthologous protein clusters analysis revealed unique genes in the $S$. Typhimurium of diverse origins studied mainly related to bacterial metabolism and that may be important in their pathogenicity;

- $S$. Typhimurium isolates from swine showed greater diversity of STs and prophages in comparison to $S$. Typhimurium strains isolated from humans and foods;

- The pathogenic potential of $S$. Typhimurium strains of diverse origins was corroborated by the presence of exclusive prophages of this serovar involved in its virulence; 
- The high number of resistance genes related to efflux pumps found in the studied $S$. Typhimurium of diverse origins is worrying and may lead to therapeutic failure when treatment is needed;

- S. Typhimurium STm30 (ST313) isolated from human feces in Brazil demonstrated greater expression of genes related to pathogenesis at $37^{\circ} \mathrm{C}$, besides better colonization and invasion in the murine colon due to higher levels of expression of virulence genes in comparison to ST19 strains;

- Pro-inflammatory cytokines were also more expressed in murine colon by STm30 (ST313) strain, suggesting greater tissue damage in comparison to S. Typhimurium SL1344 (ST19) and S. Typhimurium STm1 1 (ST19), all isolated from human feces in Brazil;

- Finally, the results obtained contributed to a better characterization of virulence and genotypic diversity of this important enteropathogen worldwide. 
REFERENCES ${ }^{1}$

${ }^{1}$ According to Brazilian Association of Technical Standards (ABNT) NBR 6023. 
ABPA (BRAZILIAN ASSOCIATION OF ANIMAL PROTEIN). Annual report 2017: pig meat (2016). Acessado em Janeiro, 18, 2021, disponível em: http://abpa-br.org/relatorios/.

ABPA (BRAZILIAN ASSOCIATION OF ANIMAL PROTEIN). Annual report 2020: pig meat (2019). Acessado em Janeiro, 18, 2021, disponível em: http://abpa-br.org/relatorios/.

AGREN, J. et al. Gegenees: fragmented alignment of multiple genomes for determining phylogenomic distances and genetic signatures unique for specified target groups. PLoS One, v. 7, n. 6, p. e39107, 2012.

ALIKHAN, N. F. et al. A genomic overview of the population structure of Salmonella. PloS Genet, v. 14, n. 4, p. e1007261, 2018.

ALLARD, M. W. et al. High resolution clustering of Salmonella enterica serovar Montevideo strains using a next-generation sequencing approach. BMC Genomics, v. 13, n. 32, p. 1-19, 2012.

ALMEIDA, F. et al. Genotypic diversity, pathogenic potential and the resistance profile of Salmonella Typhimurium strains isolated from humans and food from 1983 to 2013 in Brazil. J Med Microbiol, v. 64, n. 11, p. 1395-1407, 2015.

ALMEIDA, F. et al. Virulence-associated genes, antimicrobial resistance and molecular typing of Salmonella Typhimurium strains isolated from swine from 2000 to 2012 in Brazil. J Appl Microbiol, v. 120, n. 6, p. 1677-1690, 2016a.

ALMEIDA, F. et al. Draft genome sequences of 40 Salmonella enterica serovar Typhimurium strains isolated from humans and food in Brazil. Genome Announc, v. 4, n. 5, p. e00892, 2016b.

ALMEIDA, F. et al. Multilocus sequence typing of Salmonella Typhimurium reveals the presence of the highly invasive ST313 in Brazil. Infect Genet Evol, v. 51, p. 41-44, 2017a.

ALMEIDA, F. et al. Molecular characterization of Salmonella Typhimurium isolated in Brazil by CRISPR-MVLST. J Microbiol Methods, v. 133, p. 55-61, $2017 \mathrm{~b}$.

ALMEIDA, F. et al. Phylogenetic and antimicrobial resistance gene analysis of Salmonella Typhimurium strains isolated in Brazil by whole genome sequencing. Plos One, v. 13, p. e0201882, 2018. 
ANDERS, S.; PYL, P. T.; HUBER, W. HTSeq-a Python framework to work with highthroughput sequencing data. Bioinformatics, v. 31, n. 2, p. 166-169, 2015.

ANDREWS, S. FastQC: A Quality Control Tool for High Throughput Sequence Data [Online] (2010). Acessado em Janeiro, 18, 2021, disponível em: http://www.bioinformatics.babraham.ac.uk/projects/fastqc/

ANDREWS-POLYMENIS, H. L. et al. Taming the elephant: Salmonella biology, pathogenesis, and prevention. Infect Immun, v. 78, n. 6, p. 2356-2369, 2010.

ÂNGULO, F. J. et al. Origins and consequences of antimicrobial-resistant nontyphoidal Salmonella: implications for the use of fluoroquinolones in food animals. Microb Drug Resist, v. 6, n. 1, p. 77-83, 2000.

AO, T. T. et al. Global burden of invasive nontyphoidal Salmonella disease, 2010(1). Emerg Infect Dis, v. 21, n. 6, p. 1-9, 2015.

ARNDT, D. et al. PHASTER: a better, faster version of the PHAST phage search tool. Nucleic Acids Res, v. 44, n. W1, W16-W21, 2016.

ARYA, G. et al. Epidemiology, Pathogenesis, Genoserotyping, Antimicrobial Resistance, and Prevention and Control of Non-Typhoidal Salmonella Serovars. Curr Clin Micro Rpt, v. 5, p. 43-53, 2017.

ASOKAN, G. V. et al. WHO Global Priority Pathogens List: A Bibliometric Analysis of Medline-PubMed for Knowledge Mobilization to Infection Prevention and Control Practices in Bahrain. Oman Med J, v. 34, n. 3, p. 184-193, 2019.

ASSIS, F. E. et al. Molecular characterization of Salmonella strains isolated from outbreaks and sporadic cases of diarrhoea occurred in Paraná State, South of Brazil. Epidemiol Infect, p. 1-8, 2017.

BALASUBRAMANIAN, R. et al. The global burden and epidemiology of invasive nontyphoidal Salmonella infections. Hum Vaccin Immunother, v. 15, n. 6, p. 1421-1426, 2019.

BANKEVICH, A. et al. SPAdes: a new genome assembly algorithm and its applications to single-cell sequencing. J Comput Biol, v. 19, n. 5, p. 455-477, 2012.

BARTHEL, M. et al. Pretreatment of Mice with Streptomycin Provides a Salmonella enterica 
Serovar Typhimurium Colitis Model That Allows Analysis of Both Pathogen and Host. Infect Immun, v. 71, n. 5, p. 2839-2858, 2003.

BARUZZO, G. et al. 2017. Simulation-based comprehensive benchmarking of RNA-seq aligners. Nat Methods, v. 14, p. 135-139, 2017.

BAUMLER, A. J. HEFFRON, F. Identification and sequence analysis of $\operatorname{lp} f A B C D E$, a putative fimbrial operon of Salmonella typhimurium. J Bacteriol, v. 177, n. 8, p. 2087-2097, 1995.

BEHNSEN, J. et al. The cytokine IL-22 promotes pathogen colonization by suppressing related commensal bacteria. Immunity, v. 40, n. 2, p. 262-273, 2014.

BENEVIDES, L. et al. New insights into the diversity of the genus Faecalibacterium. Front Microbiol, v. 8, p. 1790, 2017.

BEST, E. L. et al. Multiple-locus variable-number tandem repeat analysis of Salmonella enterica subsp. enterica serovar Typhimurium: comparison of isolates from pigs, poultry and cases of human gastroenteritis. J Appl Microbiol, v. 103, n. 3, p. 565-572, 2007.

BHUNIA, A.K. Foodborne Microbial Pathogens: Mechanisms and Pathogenesis. Ed. 2. Berlin: Springer, 2018.

BOETZER, M. et al. Scaffolding pre-assembled contigs using SSPACE. Bioinformatics, v. 27, p. 578-579, 2011.

BOLGER, A. M.; LOHSE, M.; USADEL, B. Trimmomatic: a flexible trimmer for Illumina sequence data. Bioinformatics, v. 30, p. 2114-2120, 2014.

BOSI, E. et al. MeDuSa: a multi-draft based scaffolder. Bioinformatics, v. 31, p. 2443-2451, 2015.

BRAZIL. Ministério da Saúde. Manual Integrado de Vigilância, Prevenção e Controle de Doenças Transmitidas por Alimentos. p.1-160, 2010.

BRAZIL. Ministério da Saúde. Manual Técnico de Diagnóstico Laboratorial da Salmonella spp. p.1-64, 2011. 
BRAZIL. Ministério da Saúde. Surtos de Doenças Transmitidas por Alimentos no Brasil. p.1-16, 2019.

BRENNER, F. W. et al. Salmonella nomenclature. J Clin Microbiol, v. 38, n. 7, p. $2465-$ 2467, 2000.

BROZ, P.; OHLSON, M. B.; MONACK, D. M. Innate immune response to Salmonella typhimurium, a model enteric pathogen. Gut Microbes, v. 3, n. 2, p. 62-70, 2012.

BRÜSSOW, H.; CANCHAYA, C.; HARDT, W. D. Phages and the evolution of bacterial pathogens: from genomic rearrangements to lysogenic conversion. Microbiol Mol Biol Rev, v. 68 , n. 3, p. 560-602, 2004.

CALVA, E. et al. Complete genome sequencing of a multidrug-resistant and human-invasive Salmonella enterica Serovar Typhimurium strain of the emerging sequence type 213 genotype. Genome Announc, v. 3, n. 3, p. e00663, 2015.

CAMPIONI, F.; FALCÃO, J. P. Genotypic diversity and virulence markers of Yersinia enterocolitica biotype 1A strains isolated from clinical and non-clinical origins. APMIS, v. 122 , n. 3, p. 215-222, 2014.

CAMPIONI, F. et al. Prevalence of gyrA Mutations in Nalidixic Acid-Resistant Strains of Salmonella Enteritidis Isolated from Humans, Food, Chickens, and the Farm Environment in Brazil. Microb Drug Resist, v. 23, n. 4, p. 421-428, 2017.

CAMPOS, J. et al. Non-typhoidal Salmonella in the Pig Production Chain: A Comprehensive Analysis of Its Impact on Human Health. Pathogens, v. 8, n. 19, p.1-28, 2019.

CAO, G. et al. Phylogenetics and differentiation of Salmonella Newport lineages by whole genome sequencing. PLoS One, v. 8, n. 2, p. e55687, 2013.

CARATTOLI, A. et al. PlasmidFinder and pMLST: in silico detection and typing of plasmids. Antimicrob Agents Chemother, v. 58, n. 7, p. 3895-3903, 2014.

CARDEN, S. et al. Non-typhoidal Salmonella Typhimurium ST313 isolates that cause bacteremia in humans stimulate less inflammasome activation than ST19 isolates associated with gastroenteritis. Pathog Dis, v. 73, n. 4, p. ftu023, 2015.

CARVALHO, C. G. M. et al. Detection of Salmonella spp through polymerase chain reaction 
(PCR) on eggs commercialized in Fortaleza, Ceará. Nutrivisa - Revista de Nutrição e Vigilância em Saúde, v. 2, n. 3, p. 113-118, 2016.

CASAS, M. R. et al. Presence of plasmid-mediated quinolone resistance determinants and mutations in gyrase and topoisomerase in Salmonella enterica isolates with resistance and reduced susceptibility to ciprofloxacin. Diagn Microbiol Infect Dis, v. 85, n. 1, p. 85-89, 2016.

CENTERS OF DISEASE CONTROL AND PREVENTION (CDC). Whole Genome Sequencing (WGS) - PulseNet (2016). Acessado em Janeiro, 18, 2021, disponível em: https://www.cdc.gov/pulsenet/pathogens/wgs.html.

CENTERS OF DISEASE CONTROL AND PREVENTION (CDC). Salmonellosis (Nontyphoidal) (2019a). Acessado em Janeiro, 18, 2021, disponível em: https://wwwnc.cdc.gov/travel/yellowbook/2020/travel-related-infectiousdiseases/salmonellosis-nontyphoidal.

CENTERS OF DISEASE CONTROL AND PREVENTION (CDC). Drug-resistant nontyphoidal Salmonella (2019b). Acessado em Janeiro, 18, 2021, disponível em: https://www.cdc.gov/drugresistance/pdf/threats-report/nt-salmonella-508.pdf.

CENTERS OF DISEASE CONTROL AND PREVENTION (CDC). Salmonella (2018), (2020a), (2021). Acessado em Janeiro, 18, 2021, disponível em: https://www.cdc.gov/salmonella/.

CENTERS OF DISEASE CONTROL AND PREVENTION (CDC). Outbreak of Salmonella Infections Linked to Small Pet Turtles (2020b). Acessado em Janeiro, 18, 2021, disponível em: https://www.cdc.gov/salmonella/typhimurium-1-20/index.html.

CEUPPENS, S. et al. Microbial community profiling of fresh basil and pitfalls in taxonomic assignment of enterobacterial pathogenic species based upon 16S rRNA amplicon sequencing. Int J Food Microbiol, v. 257, p. 148-156, 2017.

CHEN, L. et al. VFDB: a reference database for bacterial virulence factors. Nucleic Acids Research, v. 33, p. 325-328, 2005.

CHOI, S. H. et al. Increasing incidence of quinolone resistance in human non-typhoid Salmonella enterica isolates in Korea and mechanisms involved in quinolone resistance. $\mathbf{J}$ Antimicrob Chemother, v. 56, n. 6, p. 1111-1114, 2005. 
CLSI. Clinical and Laboratory Standards Institute. Performance standards for antimicrobial susceptibility testing; twenty-fifth informational supplement. Wayne, PA, USA, 2015.

COIL, D.; JOSPIN, G.; DARLING, A. E. A5-miseq: an updated pipeline to assemble microbial genomes from Illumina MiSeq data. Bioinformatics, v. 31, p. 587-589, 2015.

COLOMBE, S. et al. Outbreak of unusual H2S-negative monophasic Salmonella Typhimurium strain likely associated with small tomatoes, Sweden, August to October 2019. Euro Surveill, v. 24, n. 47, p. 1-7, 2019.

CROUCHER, N. J. et al. A simple method for directional transcriptome sequencing using Illumina technology. Nucleic Acids Res, v. 37, n. 22, p. e148, 2009.

CUMMINGS, K. J. et al. Identification of a Plasmid-Mediated Quinolone Resistance Gene in Salmonella Isolates from Texas Dairy Farm Environmental Samples. Zoonoses Public Health, v. 64, n. 4, p. 305-307, 2017.

DAR, M. A. et al. Salmonella typhimurium in poultry: a review. World Poultry SCI J, v. 73, n. 2, p. 345-354, 2017.

DARLING, N. J. et al. Inhibition of SIK2 and SIK3 during differentiation enhances the antiinflammatory phenotype of macrophages. Biochem J, v. 474, n. 4, p. 521-537, 2017.

DAVIS, S. et al. CFSAN SNP Pipeline: an automated method for constructing SNP matrices from next-generation sequence data Peer. J Computer Science, v. 1, n. e20, p. 1-11, 2015.

DENG, W. et al. Assembly, structure, function and regulation of type III secretion systems. Nat Rev Microbiol, v. 15, n. 6, p. 323-337, 2017.

ELSNER, R. A.; SHLOMCHIK, M. J. IL-12 Blocks Tfh Cell Differentiation during Salmonella Infection, thereby Contributing to Germinal Center Suppression. Cell Rep, v. 29, n. 9, p. 2796-2809, 2019.

ESPINOZA, R. A. et al. Differential roles for pathogenicity islands SPI-13 and SPI-8 in the interaction of Salmonella Enteritidis and Salmonella Typhi with murine and human macrophages. Biol Res, v. 50, p. 5, 2017. 
European Union Summary Report on Trends and Sources of Zoonoses, Zoonotic Agents and Food-borne Outbreaks in 2012 (2014). Acessado em Janeiro, 18, 2021, disponível em: http://ecdc.europa.eu/en/publications/Publications/EU-summary-report-zoonoses-food-borneoutbreaks-2012.pdf.

EUROPEAN CENTRE FOR DISEASE PREVENTION AND CONTROL (ECDC). The European Union Summary Report on Antimicrobial Resistance in zoonotic and indicator bacteria from humans, animals and food in 2017/2018 (2020). Acessado em Janeiro, 18, 2021, disponível em: https://www.ecdc.europa.eu/en/publications/EU-summaryreport-antimicrobial-resistance-zoonoses-2017-2018.

EVANGELOPOULOU, G. et al. The commercial impact of pig Salmonella spp. infections in border-free markets during an economic recession. Vet World, v. 8, n. 3, p. 257-272, 2015.

FÀBREGA, A.; VILA, J. Salmonella enterica serovar Typhimurium skills to succeed in the host: virulence and regulation. Clin Microbiol Rev, v. 26, n. 2, p. 308-341, 2013.

FEASEY, N. A. et al. Invasive non-typhoidal Salmonella disease: an emerging and neglected tropical disease in Africa. Lancet, v. 379, n. 9835, p. 2489-2499, 2012.

FEASEY, N. A. et al. Drug resistance in Salmonella enterica ser. Typhimurium bloodstream infection, Malawi. Emerg Infect Dis, v. 20, n. 11, p. 1957-1959, 2014.

FERNANDES, S. A. et al. Salmonella serovars isolated from humans in São Paulo State, Brazil, 1996-2003. Rev Inst Med Trop Sao Paulo, v. 48, n. 4, p. 179-184, 2006.

FERRARI, R. G. et al. Worldwide Epidemiology of Salmonella Serovars in Animal-Based Foods: a Meta-analysis. Appl Environ Microbiol, v. 85, n. 14, p. e00591-19, 2019.

FERREIRA, M. E.; BORGES NETO, C. R. A importância da pesquisa genômica e o sequenciamento de DNA. EMPRAPA Recursos genéticos e Biotecnologia, p. 1-4, 2003.

FERREIRA, E. O.; CAMPOS, L. C. Salmonella. In: TRABULSI, L. R.; ALTERTHUM, F. Microbiologia. 5 ed. São Paulo: Atheneu, 2008. Cap. 43, p. 329-338.

FIERER, J. et al. Expression of the Salmonella virulence plasmid gene $s p v B$ in cultured macrophages and nonphagocytic cells. Infect Immun, v. 61, n. 12, p. 5231-5236, 1993.

FIGUEIRA, R.; HOLDEN, D. W. Functions of the Salmonella pathogenicity island 2 (SPI-2) 
type III secretion system effectors. Microbiology, v. 158, p. 1147-1161, 2012.

FIGUEROA-BOSSI, N.; BOSSI, L. Inducible prophages contribute to Salmonella virulence in mice. Mol Microbiol, v. 33, n. 1, p. 167-176, 1999.

FINLAY, B. B.; RUSCHKOWSKI, S.; DEDHAR, S. Cytoskeletal rearrangements accompanying Salmonella entry into epithelial cells. J Cell Sci, v. 99, p. 283-296, 1991.

GALÁN, J. E. Salmonella interactions with host cells: type III secretion at work. Annu Rev Cell Dev Biol, v. 17, p. 53-86, 2001.

GARCÍA, P. et al. Genetic types, gene repertoire, and evolution of isolates of the Salmonella enterica serovar 4,5,12:i:- Spanish clone assigned to different phage types. J Clin Microbiol, v. 51, n. 3, p. 973-978, 2013.

GILCHRIST, J. J.; MACLENNAN, C. A.; HILL, A. V. Genetic susceptibility to invasive Salmonella disease. Nat Rev Immunol, v. 15, n. 7, p. 452-463, 2015.

GILCHRIST, J. J.; MACLENNAN, C. A. Invasive Nontyphoidal Salmonella Disease in Africa. EcoSal Plus, v. 8, n. 2, p. 1-23, 2019.

GODÍNEZ-OVIEDO, A. et al. Salmonella enterica in Mexico 2000-2017: Epidemiology, Antimicrobial Resistance, and Prevalence in Food. Foodborne Pathog Dis, v. 17, n. 2, p. 98 118,2020

GRUZDEV, N. et al. Global transcriptional analysis of dehydrated Salmonella enterica serovar Typhimurium. Appl Environ Microbiol, v. 78, n. 22, p. 7866-7875, 2012.

GUINEY, D. G. et al. Biology and clinical significance of virulence plasmids in Salmonella serovars. Clin Infect Dis, v. 21 Suppl 2, p. S146-151, 1995.

GUREVICH, A. et al. QUAST: quality assessment tool for genome assemblies. Bioinformatics, v. 29, n. 8, p. 1072-1075, 2013.

HAPFELMEIER, S. et al. Role of the Salmonella pathogenicity island 1 effector proteins SipA, SopB, SopE, and SopE2 in Salmonella enterica subspecies 1 serovar Typhimurium colitis in streptomycin-pretreated mice. Infect Immun, v. 72, n. 2, p. 795-809, 2004. 
HAWKEY, J. et al. Evidence of microevolution of Salmonella Typhimurium during a series of egg-associated outbreaks linked to a single chicken farm. BMC Genomics, v. 14, p. 800, 2013.

HEATHER, J. M.; CHAIN, B. The sequence of sequencers: The history of sequencing DNA. Genomics, v. 107, n. 1, p. 1-8, 2016.

HEIJDEN, J.; FINLAY, B. B. Type III effector-mediated processes in Salmonella infection. Future Microbiol, v. 7, n. 6, p. 685-703, 2012.

HELMS, M. et al. Excess mortality associated with antimicrobial drug resistant Salmonella typhimurium. Emerg Infect Dis, v. 8, n. 5, p. 490-495, 2002.

HENDRIKSEN, R. S. et al. Global monitoring of Salmonella serovar distribution from the World Health Organization Global Foodborne Infections Network Country Data Bank: results of quality assured laboratories from 2001 to 2007. Foodborne Pathog Dis, v. 8, n. 8, p. 887900, 2011.

HERRERO-FRESNO, A. et al. The role of the st313-td gene in virulence of Salmonella Typhimurium ST313. Plos One, v. 9, n. 1, p. e84566, 2014.

HILEY, L.; GRAHAM, R. M.; JENNISON, A. V. Genetic characterisation of variants of the virulence plasmid, pSLT, in Salmonella enterica serovar Typhimurium provides evidence of a variety of evolutionary directions consistent with vertical rather than horizontal transmission. PloS One, v. 14, n. 4, p. e0215207, 2019.

HOFFMANN, M. et al. Comparative genomic analysis and virulence differences in closely related Salmonella enterica serotype Heidelberg isolates from humans, retail meats, and animals. Genome Biol Evol, v. 6, n. 5, p. 1046-1068, 2014.

HOHMANN, E. L. Nontyphoidal salmonellosis. Clin Infect Dis, v. 32, n. 2, p. 263-269, 2001.

HOLLEY, R. W. et al. Nucleotide Sequences in the Yeast Alanine Transfer Ribonucleic Acid. J Biol Chem, v. 240, p. 2122-2128, 1965.

HOPKINS, K. L.; DAY, M.; THRELFALL, E. J. Plasmid-mediated quinolone resistance in Salmonella enterica, United Kingdom. Emerg Infect Dis, v. 14, n. 2, p. 340-342, 2008. 
HORIYAMA, T.; YAMAGUCHI, A.; NISHINO, K. TolC dependency of multidrug efflux systems in Salmonella enterica serovar Typhimurium. J Antimicrob Chemother, v. 65, n. 7 , p. 1372-1376, 2010.

HURLEY, D. et al. Salmonella-host interactions - modulation of the host innate immune system. Front Immunol, v. 5, p. 481, 2014.

HUSON, D. H.; KLOEPPER, T. H. Computing recombination networks from binary sequences. Bioinformatics, v. 21(Suppl 2), p. ii159-ii165, 2005.

IBARRA, J. A.; STEELE-MORTIMER, O. Salmonella - the ultimate insider. Salmonella virulence factors that modulate intracellular survival. Cell Microbiol, v. 11, n. 11, p. 15791586, 2009.

ILLUMINA. An Introduction to Illumina Next-Generation Sequencing Technology for Microbiologists (2021). Acessado em Janeiro, 18, 2021, disponível em: https://www.illumina.com/areas-of-interest/microbiology/microbial-sequencing-methods.html

ISSENHUTH-JEANJEAN, S. et al. Supplement 2008-2010 (no. 48) to the White-KauffmannLe Minor scheme. Res Microbiol, v. 165, n. 7, p. 526-530, 2014.

JACOBY, G. A.; STRAHILEVITZ, J.; HOOPER, D.C. Plasmid-mediated quinolone resistance. Microbiol Spectr, v. 2, n. 5, p. 1-42, 2014.

JAJERE, S. M. A review of Salmonella enterica with particular focus on the pathogenicity and virulence factors, host specificity and antimicrobial resistance including multidrug resistance. Vet World, v. 12, n. 4, p. 504-521, 2019.

JARVIS, K. G. et al. Cilantro microbiome before and after nonselective pre-enrichment for Salmonella using 16S rRNA and metagenomic sequencing. BMC Microbiol, v. 15, p. 160, 2015.

JENSEN, R. A. Orthologs and paralogs - we need to get it right. Genome Biol, v. 2, n. 8, p. interactions 1002, 2012.

JIANG, X. et al. The related effector proteins SopD and SopD2 from Salmonella enterica serovar Typhimurium contribute to virulence during systemic infection of mice. Mol Microbiol, v. 54, n. 5, p. 1186-1198, 2004. 
JIANG, L. et al. LoiA directly represses lon gene expression to activate the expression of Salmonella pathogenicity island-1 genes. Res Microbiol, v. 170, p. 131-137, 2019.

JOENSEN, K. G. et al. Evaluating next-generation sequencing for direct clinical diagnostics in diarrhoeal disease. Eur J Clin Microbiol Infect Dis, v. 36, n. 7, p. 1325-1338, 2017.

JONG, H. K. et al. Host-pathogen interaction in invasive Salmonellosis. PLoS Pathog, v. 8, n. 10, p. e1002933, 2012.

KARAOLIS, D. K. R. Pathogenicity islands. Encyclopedia of Genetics, p. 1422-1424, 2001.

KARIUKI, S.; ONSARE, R. S. Epidemiology and Genomics of Invasive Nontyphoidal Salmonella Infections in Kenya. Clin Infect Dis, 61 Suppl 4, p. S317-324, 2015.

$\mathrm{KICH}$, J. D. et al. Prevalence, distribution, and molecular characterization of Salmonella recovered from swine finishing herds and a slaughter facility in Santa Catarina, Brazil. Int $\mathbf{J}$ Food Microbiol, v. 151, n. 3, p. 307-313, 2011.

KIM, M. et al. Towards a taxonomic coherence between average nucleotide identity and $16 \mathrm{~S}$ rRNA gene sequence similarity for species demarcation of prokaryotes. Int J Syst Evol Microbiol, v. 64, n. Pt2, p. 346-351, 2014.

KIMBROUGH, T. G.; MILLER, S. I. Assembly of the type III secretion needle complex of Salmonella typhimurium. Microbes Infect, v. 4, n. 1, p. 75-82, 2002.

KINGSLEY, R. A. et al. Epidemic multiple drug resistant Salmonella Typhimurium causing invasive disease in sub-Saharan Africa have a distinct genotype. Genome Res, v. 19, n. 12, p. 2279-2287, 2009.

KIRK, M. D. et al. World Health Organization Estimates of the Global and Regional Disease Burden of 22 Foodborne Bacterial, Protozoal, and Viral Diseases, 2010: A Data Synthesis. PLoS Med, v. 12, n. 12, p. e1001921, 2015.

KLIMKE, W. et al. The National Center for Biotechnology Information's Protein Clusters Database. Nucleic Acids Res, v. 37, p. 216-223, 2009.

KLUMPP, J.; FUCHS, T. M. Identification of novel genes in genomic islands that contribute to Salmonella typhimurium replication in macrophages. Microbiology, v. 153, n. Pt4, p. 
1207-1220, 2007.

KNODLER, L. A. et al. Salmonella type III effectors PipB and PipB2 are targeted to detergent-resistant microdomains on internal host cell membranes. Mol Microbiol, v. 49, n. 3, p. 685-704, 2003.

KONSTANTINIDIS, K. T.; TIEDJE, J. M. Genomic insights that advance the species definition for prokaryotes. Proc Natl Acad Sci, v. 102, n. 7, p. 2567-2572, 2005.

KROGER, C. et al. The transcriptional landscape and small RNAs of Salmonella enterica serovar Typhimurium. Proc Natl Acad Sci U S A, v. 109, p. E1277-E1286, 2012.

KROPINSKI, A. M. Measurement of the Bacteriophage Inactivation Kinetics with Purified Receptors. In: CLOKIE, M. R.; KROPINSKI, A. M. Bacteriophages: Methods and Protocols, ed. New York: Springer, 2009. v. 1, Cap. 16, p. 157-160.

KUIJPERS, A. F. A. et al. Phenotypic Prediction: Linking in vitro Virulence to the Genomics of 59 Salmonella enterica Strains. Front Microbiol, v. 9, p. 3182, 2018.

LANGMEAD, B.; SALZBERG, S. L. Fast gapped-read alignment with Bowtie 2. Nat Methods, v. 9, p. 357-359, 2012.

LAROCK, D. L.; CHAUDHARY, A.; MILLER, S. I. Salmonellae interactions with host processes. Nat Rev Microbiol, v. 13, n. 4, p. 191-205, 2015.

LARSEN, M. V. et al. Multilocus sequence typing of total-genome-sequenced bacteria. J Clin Microbiol, v. 50, n. 4, p. 1355-1361, 2012.

LEDEBOER, N. A. et al. Salmonella enterica serovar Typhimurium requires the Lpf, Pef, and Tafi fimbriae for biofilm formation on HEp-2 tissue culture cells and chicken intestinal epithelium. Infect Immun, v. 74, n. 6, p. 3156-3169, 2006.

LEE, I. et al. OrthoANI: an improved algorithm and software for calculating average nucleotide identity. Int J Syst Evol Microbiol, v. 66, n. 2, p. 1100-1103, 2016.

LEY, B. et al. Invasive Salmonella enterica serotype typhimurium infections, Democratic Republic of the Congo, 2007-2011. Emerg Infect Dis, v. 20, n. 4, p. 701-704, 2014. 
LI, L.; STOECKERT, C. J.; ROOS, D. S. OrthoMCL: identification of ortholog groups for eukaryotic genomes. Genome Res, v. 13, n. 9, p. 2178-2189, 2003.

LI, L. et al. RNA-seq-based analysis of drug-resistant Salmonella enterica serovar Typhimurium selected in vivo and in vitro. PloS ONE, v. 12, n. 4, p. e0175234, 2017.

LIU, Y. Y.; CHIOU, C. S.; CHEN, C. C. PGAdb-builder: a web service tool for creating pangenome allele database for molecular fine typing. Sci Rep, v. 6, p. 36213, 2016.

LIU, X. et al. Changes in inflammatory and oxidative stress factors and the protein synthesis pathway in injured skeletal muscle after contusion. Exp Ther Med, v. 15, n. 2, p. 2196-2202, 2018.

LOVE, M. I.; HUBER, W.; ANDERS, S. Moderated estimation of fold change and dispersion for RNA-seq data with DESeq2. Genome Biology, v. 15, p. 550, 2014.

MACLENNAN, C. A. et al. Presentation of life-threatening invasive nontyphoidal Salmonella disease in Malawian children: A prospective observational study. PLoS Negl Trop Dis, v. 11, n. 12 , p. e0006027, 2017.

MAHATO, N. K. et al. Microbial taxonomy in the era of OMICS: application of DNA sequences, computational tools and techniques. Antonie Van Leeuwenhoek, v. 110, n. 10, p. 1357-1371, 2017.

MAIDEN, M. C. et al. MLST revisited: the gene-by-gene approach to bacterial genomics. Nat Rev Microbiol, v. 11, n. 10, p. 728-736, 2013.

MAJOWICZ, S. E. et al. The global burden of nontyphoidal Salmonella gastroenteritis. Clin Infect Dis, v. 50, n. 6, p. 882-889, 2010.

MCARTHUR, A. G. et al. The comprehensive antibiotic resistance database. Antimicrob Agents Chemother, v. 57, n. 7, p. 3348-3357, 2013.

MCCLELLAND, M. et al. Complete genome sequence of Salmonella enterica serovar Typhimurium LT2. Nature, v. 413, p. 852-855, 2001.

MCDERMOTT, P. F. et al. Whole-Genome Sequencing for Detecting Antimicrobial Resistance in Nontyphoidal Salmonella. Antimicrob Agents Chemother, v. 60, n. 9, p. 5515-5520, 2016. 
MCGUIRE, V. A. et al. Dimethyl fumarate blocks proinflammatory cytokine production via inhibition of TLR induced M1 and K63 ubiquitin chain formation. Sci Rep, v. 8, p. 31159, 2016.

MCLAUGHLIN, L. M. et al. A microfluidic-based genetic screen to identify microbial virulence factors that inhibit dendritic cell migration. Integr Biol (Camb.), v. 6, n. 4, p. 438449, 2014.

MI, H. et al. Protocol Update for Large-Scale Genome and Gene Function Analysis With the PANTHER Classification System (v.14.0). Nat Protocols, v. 14, p. 703-721, 2019.

MIRYALA, S. K.; RAMAIAH, S. Exploring the multi-drug resistance in Escherichia coli O157:H7 by gene interaction network: A systems biology approach. Genomics, v. 111, n. 4, p. 958-965, 2019.

MOFFATT, C. R. et al. Salmonella Typhimurium and outbreaks of egg-associated disease in Australia, 2001 to 2011. Foodborne Pathog Dis, v. 13, n. 7, p. 379-385, 2016.

MØLBAK, K. et al. An outbreak of multidrug-resistant, quinolone-resistant Salmonella enterica serotype typhimurium DT104. N Engl J Med, v. 341, n. 19, p. 1420-1425, 1999.

MOLLO, B. et al. Intrauterine infection caused by nontyphoidal Salmonella: a literature review. J Matern Fetal Neonatal Med, p. 1-5, 2019.

MOREIRA, C. G.; WEINSHENKER, D.; SPERANDIO, V. QseC mediates Salmonella enterica serovar typhimurium virulence in vitro and in vivo. Infect Immun, v. 78, n. 3, p. 914-926, 2010.

NADALIN, F.; VEZZI, F.; POLICRITI, A. GapFiller: a de novo assembly approach to fill the gap within paired reads. BMC Bioinformatics, v. 13 Suppl 14, p. S8, 2012.

NATIONAL ANTIMICROBIAL RESISTANCE MONITORING SYSTEM FOR ENTERIC BACTERIA (NARMS). Antibiotic Resistance and NARMS Surveillance (2020). Acessado em Janeiro, 18, 2021, disponível em: https://www.cdc.gov/narms/index.html.

NATARO, J. P.; BOPP, C. A.; FIELDS, P. I.; KAPER, J. B.; STROCKBINE, N. A. Escherichia, Shigella, and Salmonella. In: VERSALOVIC, J.; CARROLL, K. C.; FUNKE, G.; JORGENSEN J. H.; LANDRY, M. L.; WARNOCK D. W. Manual of Clinical Microbiology. 10 ed. Washington: ASM Press, 2011. V. 1, Cap. 35, p. 603-26. 
NGOI, S. T.; YAP, K. P.; THONG, K. L. Genomic characterization of endemic Salmonella enterica serovar Typhimurium and Salmonella enterica serovar I 4,[5],12:i:- isolated in Malaysia. Infect Genet Evol, v. 62, p. 109-121, 2018.

NURK, S. et al. Assembling single-cell genomes and mini-metagenomes from chimeric MDA products. J Comput Biol, v. 20, n. 10, p. 714-37, 2013.

OKORO, C. K. et al. Intracontinental spread of human invasive Salmonella Typhimurium pathovariants in sub-Saharan Africa. Nat Genet, v. 44, n. 11, p. 1215-1221, 2012.

OKORO, C. K. et al. Signatures of adaptation in human invasive Salmonella Typhimurium ST313 populations from sub-Saharan Africa. PLoS Negl Trop Dis, v. 9, n. 3, p. e0003611, 2015.

O' NEILL, J. Antimicrobial Resistance: Tackling a crisis for the health and wealth of nations. Rev on Antimicrob Res, p. 1-20, 2014.

OSHOTA, O. et al. Transcriptome and proteome analysis of Salmonella enterica serovar Typhimurium systemic infection of wild type and immunedeficient mice. PloS ONE, v. 12, n. 8, p. e0181365, 2017.

ÖSTERBERG, J.; LEWERIN, S. S.; WALLGREN, P. Direct and indirect transmission of four Salmonella enterica serotypes in pigs. Acta Vet Scand, v. 52, p. 30, 2010.

PAIM, D. S. et al. Enumeration, Antimicrobial Resistance and Typing of Salmonella enterica: Profile of Strains Carried in the Intestinal Contents of Pigs at Slaughter in Southern Brazil. Acta Sci Vet, v. 47, p. 1636, 2019.

PANG, S. et al. Genomic diversity and adaptation of Salmonella enterica serovar Typhimurium from analysis of six genomes of different phage types. BMC Genomics, v. 14, p. 718, 2013.

PANZENHAGEN, P. H. N. et al. Genetically distinct lineages of Salmonella Typhimurium ST313 and ST19 are present in Brazil. Int J Med Microbiol, v. 308, n. 2, p. 306-316, 2018.

PENG, Y. et al. IDBA-UD: a de novo assembler for single-cell and metagenomic sequencing data with highly uneven depth. Bioinformatics, v. 28, p. 1420-1428, 2012.

PEREZ, K. J. et al. Evaluation of intestinal invasion in germ-free mice challenged with acid- 
adapted and nonacid-adapted Salmonella Enteritidis SE86 and Salmonella Typhimurium ST99. J Food Safety, v. 32, n. 1, 108-114, 2012.

PETERSEN, E.; MILLER, S. I. The cellular microbiology of Salmonellae interactions with macrophages. Cell Microbiol, v. 21, n. 11, p. e13116, 2019.

PETKAU, A. et al. Interactive microbial genome visualization with GView. Bioinformatics, v. 26, p. 3125-3126, 2010.

PETTENGILL, J. B.; RAND, H. Segal's law, 16S rRNA gene sequencing, and the perils of foodborne pathogen detection within the American Gut Project. Peer J, v. 5, p. e3480, 2017.

PFEIFER, C. G. et al. Salmonella Typhimurium virulence genes are induced upon bacterial invasion into phagocytic and nonphagocytic cells. Infect Immun, v. 67, n. 11, p. 5690-5698, 1999.

PHILLIPS, A. et al. Whole genome sequencing of Salmonella Typhimurium illuminates distinct outbreaks caused by an endemic multi-locus variable number tandem repeat analysis type in Australia, 2014. BMC Microbiol, v. 16, p. 211, 2016.

PIDDOCK, L. J. V. Understanding the basis of antibiotic resistance: a platform for drug discovery. Microbiology (Reading), v. 160, n. Pt11, p. 2366-2373, 2014.

PORTER, S. et al. Trends in Salmonella serovars and antimicrobial resistance in pigs and poultry in Northern Ireland between 1997 and 2016. Vet Rec, v. 186, n. 5, p. 156, 2020.

PRIBUL, B. R. et al. Characteristics of Quinolone Resistance in Salmonella spp. isolates from the Food Chain in Brazil. Front Microbiol, v. 8, p. 299, 2017.

PULFORD, C. V. et al. Stepwise evolution of Salmonella Typhimurium ST313 causing bloodstream infection in Africa. Nat Microbiol, 2020.

QUAST, C. et al. The SILVA ribosomal RNA gene database project: improved data processing and web-based tools. Nucleic Acids Res, v. 41, p. D590-D596, 2013.

RABSCH, W. et al. Salmonella enterica serotype Typhimurium and its host-adapted variants. Infect Immun, v. 70, n. 5, p. 2249-55, 2002. 
RAMACHANDRAN, G. et al. Invasive Salmonella Typhimurium ST313 with naturally attenuated flagellin elicits reduced inflammation and replicates within macrophages. PLoS Negl Trop Dis, v. 9, n. 1, p. e3394, 2015.

RAMACHANDRAN, G. et al. Virulence of invasive Salmonella Typhimurium ST313 in animal models of infection. PLoS Negl Trop Dis, v. 11, n. 8, p. e0005697, 2017.

REDDY, E. A.; SHAW, A. V.; CRUMP, J. A. Community-acquired bloodstream infections in Africa: a systematic review and meta-analysis. Lancet Infect Dis, v. 10, n. 6, p. 417-432, 2010 .

RENWICK, J. et al. Susceptibility of larvae of Galleria mellonella to infection by Aspergillus fumigatus is dependent upon stage of conidial germination. Mycopathologia, v. 161, p. 377384, 2006.

RODRÍGUEZ, D. M.; SUÁREZ, M. C. Salmonella spp. in the pork supply chain: a risk approach. Rev Colomb Cienc Pecu, v. 27, p. 65-75, 2014.

ROER, L. et al. Is the Evolution of Salmonella enterica subsp. enterica Linked to RestrictionModification Systems. mSystems, v. 1, p. e00009-16, 2016.

RYCHLIK, I.; GREGOROVA, D.; HRADECKA, H. Distribution and function of plasmids in Salmonella enterica. Vet Microbiol, v. 112, n. 1, p. 1-10, 2006.

SÁENZ Y. et al. Mutations in gyrA and $\operatorname{parC}$ genes in nalidixic acid-resistant Escherichia coli strains from food products, humans and animals. J Antimicrob Chemother, v. 51, n. 4, p. 1001-5, 2003.

SALAZAR, G. A. et al. Interleukin-10 Production by $\mathrm{T}$ and $\mathrm{B}$ Cells Is a Key Factor to Promote Systemic Salmonella enterica Serovar Typhimurium Infection in Mice. Front Immunol, v. 8, p. 889, 2017.

SANGER, F.; BROWNLEE, G. G.; BARRELL, B. G. A two-dimensional fractionation procedure for radioactive nucleotides. J Mol Biol, v. 13, n. 2, p. 373-398, 1965.

SANTOS, A. M. P.; FERRARI, R. G.; CONTE-JUNIOR, C. A. Virulence Factors in Salmonella Typhimurium: The Sagacity of a Bacterium. Curr Microbiol, v. 76, n. 6, p. 762$773,2019$. 
SCALLAN, E. et al. Foodborne illness acquired in the United States - major pathogens. Emerg Infect Dis, v. 17, n. 1, p. 7-15, 2011.

SCHULTE, M.; HENSEL, M. Models of intestinal infection by Salmonella enterica: introduction of a new neonate mouse model. F1000Res, v. 5, 2016.

SENTAUSA, E.; FOURNIER, P. E. Advantages and limitations of genomics in prokaryotic taxonomy. Clin Microbiol Infect, v. 19, n. 9, p. 790-795, 2013.

SERIBELLI, A. A. et al. Phylogenetic Analysis Revealed That Salmonella Typhimurium ST313 Isolated From Humans and Food in Brazil Presented a High Genomic Similarity. Braz J Microbiol, v. 51, n. 1, p. 53-64, 2019.

SERIBELLI, A. A. et al. Phenotypic and genotypic characterization of Salmonella Typhimurium isolates from humans and foods in Brazil. PLoS One, v. 15, n. 8, p. e0237886, 2020.

SHIVANI, C. et al. Comparative genome analysis of three pathogenic strains of E. coli, Salmonella and Shigella. IJSRR, v. 4, n. 1, p. 68-80, 2015.

SILVA, C. et al. Complete genome sequence of Salmonella enterica serovar Typhimurium strain SO2 (sequence type 302) isolated from an asymptomatic child in Mexico. Genome Announc, v. 4, n. 2, p. e00253, 2016 a.

SILVA, C. et al. Complete genome sequence of Salmonella enterica serovar Typhimurium strain YU15 (sequence type 19) harboring the Salmonella genomic island 1 and virulence plasmid pSTV. Genome Announc, v. 4, n. 2, p. e00252, 2016 b.

SIMON, S. et al. Evaluation of WGS based approaches for investigating a foodborne outbreak caused by Salmonella enterica serovar Derby in Germany. Food Microbiol, v. 71, p. 46-54, 2018.

SIMPSON, J. T.; DURBIN, R. Efficient de novo assembly of large genomes using compressed data structures. Genome Res, v. 22, p. 549-556, 2012.

SINGLETARY, L. A. et al. Loss of Multicellular Behavior in Epidemic African Nontyphoidal Salmonella enterica Serovar Typhimurium ST313 Strain D23580. MBio, v. 7, n. 2, p. e02265, 2016. 
SRINIVASAN, R. et al. Use of $16 \mathrm{~S}$ rRNA gene for identification of a broad range of clinically relevant bacterial pathogens. PLoS One, v. 10, n. 2, p. e0117617, 2015.

SUN, J.; DENG, Z.; YAN, A. Bacterial multidrug efflux pumps: mechanisms, physiology and pharmacological exploitations. Biochem Biophys Res Commun, v. 453, n. 2, p. 254-267, 2014.

SUN, H. et al. A family of Salmonella type III secretion effector proteins selectively targets the NF- $\kappa \mathrm{B}$ signaling pathway to preserve host homeostasis. Plos Pathog, v. 12, n. 3, p. e1005484, 2016.

SWITT, A. I. M. et al. Salmonella Phages and Prophages: Genomics, Taxonomy, and Applied Aspects In: SCHATTEN, H.; EISENSTARK, A. Salmonella. Methods in Molecular Biology (Methods and Protocols), ed. New York: Springer, 2015. v. 1, Cap. 15, p. 237-87.

TAMURA, K. et al. MEGA6: Molecular evolutionary genetics analysis version 6.0. Mol Biol Evol, v. 30, n. 12, p. 2725-2729, 2013.

TANG, H. Regulation and function of the melanization reaction in Drosophila. Fly (Austin), v. 3, n. 1, p. 105-111, 2009.

TAUNAY, A. E. et al. The role of public health laboratory in the problem of salmonellosis in São Paulo, Brazil. Rev Inst Med Trop São Paulo, v. 38, n. 2, p. 119-27, 1996.

TAVECHIO, A. T. et al. Changing patterns of Salmonella serovars: increase of Salmonella enteritidis in São Paulo, Brazil. Rev Inst Med Trop São Paulo, v. 38, n. 5, p. :315-22, 1996.

TAVECHIO, A. T. et al. Salmonella serotypes isolated from nonhuman sources in São Paulo, Brazil, from 1996 through 2000. J Food Prot, v. 65, n. 6, p. 1041-4, 2002.

THIJS, I. M. V. et al. Delineation of the Salmonella enterica Serovar Typhimurium HilA Regulon through Genome-Wide Location and Transcript Analysis. J Bacteriol, v. 189, n. 13, p. 4587-4596, 2007.

TIMME, R. E. et al. Phylogenetic diversity of the enteric pathogen Salmonella enterica subsp. enterica inferred from genome-wide reference-free SNP characters. Genome Biol Evol, v. 5, n. 11, p. 2109-23, 2013.

TRKOV, M.; AVGUSTIN, G. An improved 16S rRNA based PCR method for the specific 
detection of Salmonella enterica. Int J Food Microbiol, v. 80, n. 1, p. 67-75, 2003.

TSAI, C. J.; LOH, J. M.; PROFT, T. Galleria mellonella infection models for the study of bacterial diseases and for antimicrobial drug testing. Virulence, v. 7, n. 3, p. 214-229, 2016.

UCHE, I. V.; MACLENNAN, C. A.; SAUL, A. A. Systematic Review of the Incidence, Risk Factors and Case Fatality Rates of Invasive Nontyphoidal Salmonella (iNTS) Disease in Africa (1966 to 2014). PLoS Negl Trop Dis, v. 11, n. 1, p. e0005118, 2017.

UNIVERSAL PROTEIN RESOURCE (UniProt). Resistance genes (2020). Acessado em Janeiro, 2021, 18, disponível em: https://www.uniprot.org/uniref/?query=resistance+genes\&sort=score.

VALERI, M.; RAFFATELLU, M. Cytokines IL-17 and IL-22 in the host response to infection. Pathog Dis, v. 74, n. 9, p. 1-15, 2016.

VILLA, L. et al. Replicon sequence typing of IncF plasmids carrying virulence and resistance determinants. J Antimicrob Chemother, v. 65, n. 12, p. 2518-2529, 2010.

VINUESA, P. et al. Complete genome sequence of Salmonella enterica Serovar Typhimurium strain SO3 (sequence type 302) isolated from a baby with meningitis in Mexico. Genome Announc, v. 4, n. 2, p. e00285, 2016.

VIOTT, A. M. et al. The prevalence of swine enteropathogens in Brazilian grower and finish herds. Braz J Microbiol, v. 44, n. 1, p. 145-51, 2013.

WAHL, A.; BATTESTI, A.; ANSALDI, M. Prophages in Salmonella enterica: a driving force in reshaping the genome and physiology of their bacterial host? Mol Microbiol, v. 111, n. 2, p. 303-316, 2019.

WALTERS, M.; SPERANDIO, V. Autoinducer 3 and Epinephrine Signaling in the Kinetics of Locus of Enterocyte Effacement Gene Expression in Enterohemorrhagic Escherichia coli. Infect Immun, v. 74, n. 10, p. 5445-5455, 2006.

WANG, Y. et al. OrthoVenn: a web server for genome wide comparison and annotation of orthologous clusters across multiple species. Nucleic Acids Res, v. 43, n. W1, p. W78-84, 2015 .

WANG, $\mathrm{H}$. et al. Identification of antibiotic resistance genes in the multidrug-resistant 
Acinetobacter baumannii strain, MDR-SHH02, using whole-genome sequencing. Int J Mol Med, v. 39, n. 2, p. 364-72, 2017.

WANG, X. et al. Genetic boundaries delineate the potential human pathogen Salmonella bongori into discrete lineages: divergence and speciation. BMC Genomics, v. 20, n. 1, p. 930, 2019a.

WANG, X. et al. Antibiotic Resistance in Salmonella Typhimurium Isolates Recovered From the Food Chain Through National Antimicrobial Resistance Monitoring System Between 1996 and 2016. Front Microbiol, v. 10, p. 985, 2019 b.

WANG, J. et al. Characterization of Salmonella enterica Isolates from Diseased Poultry in Northern China between 2014 and 2018. Pathogens, v. 9, n. 2, p. E95, 2020a.

WANG, M. et al. Salmonella virulence and immune scape. Microorganisms, v. 8, p. 1-25, 2020 b.

WEMYSS, M. A.; PEARSON, J. S. Host Cell Death Responses to Non-typhoidal Salmonella Infection. Front Immunol, v. 10, p. 1758, 2019.

WESTERMAN, T. L. et al. The Salmonella type-3 secretion system-1 and flagellar motility influence the neutrophil respiratory burst. PLoS One, v. 13, n. 9, p. e0203698, 2018.

WONG, M. H. et al. Expansion of Salmonella enterica Serovar Typhimurium ST34 clone carrying multiple resistance determinants in China. Antimicrob Agents Chemother, v. 57, n. 9, p. 4599-4601, 2013.

WOOD, M. W. et al. Identification of a pathogenicity island required for Salmonella enteropathogenicity. Mol Microbiol, v. 29, n. 3, p. 883-891, 1998.

WORK, T. M. et al. A novel host-adapted strain of Salmonella Typhimurium causes renal disease in olive ridley turtles (Lepidochelys olivacea) in the Pacific. Sci Rep, v. 9, n. 1, p. 9313, 2019.

WORLD HEALTH ORGANIZATION (WHO). Salmonella (non-typhoidal) (2018). Acessado em Janeiro, 18, 2021, disponível em: https:/www.who.int/en/news-room/factsheets/detail/salmonella-(non-typhoidal). 
Janeiro, 18, 2021, disponível em: https:/www.who.int/news-room/factsheets/detail/antibiotic-resistance.

WU, G. et al. Epidemic multidrug-resistant (MDR-AmpC) Salmonella enterica serovar Newport strains contain three phage regions and a MDR resistance plasmid. Environ Microbiol Rep, v. 2, n. 2, p. 228-235, 2010.

WU, Y. W. ezTree: an automated pipeline for identifying phylogenetic marker genes and inferring evolutionary relationships among uncultivated prokaryotic draft genomes. BMC Genomics, v. 19, n. Suppl 1, p. 921, 2018.

$\mathrm{XU}$, L. et al. OrthoVenn2: a web server for whole-genome comparison and annotation of orthologous clusters across multiple species. Nucleic Acids Res, v. 47, n. W1, p. W52-W8, 2019.

YAMAKAWA, I. et al. Inactivation of TNF- $\alpha$ ameliorates diabetic neuropathy in mice. Am $\mathbf{J}$ Physiol Endocrinol Metab, v. 301, n. 5, p. E844-E852, 2011.

YANG, J. et al. Characterization of the Invasive, Multidrug Resistant Non-typhoidal Salmonella Strain D23580 in a Murine Model of Infection. PLoS Negl Trop Dis, v. 9, n. 6, p. e0003839, 2015a.

YANG, X. et al. Prevalence and Characterization of Monophasic Salmonella Serovar 1,4,[5],12:i:- of Food Origin in China. PLoS One, v. 10, n. 9, p. e0137967, 2015 b.

YI, H.; CHUN, J. Neisseria weaveri Andersen et al 1993 is a later heterotypic synonym of Neisseria weaveri Holmes et al. 1993. Int J Syst Evol Microbiol, v. 65, n. (Pt2), p. 463-464, 2015.

YILMAZ, P. et al. The SILVA and "all-species living tree project (LTP)" taxonomic frameworks. Nucleic Acids Res, v. 42, p. D643-D648, 2014.

YOSHIDA, H. et al. Quinolone resistance-determining region in the DNA gyrase gyrB gene of Escherichia coli. Antimicrob Agents Chemother, v. 35, n. 8, p. 1647-50, 1991.

YOSHIDA, C. et al. Evaluation of Molecular Methods for Identification of Salmonella Serovars. J Clin Microbiol, v. 54, n. 8, p. 1992-8, 2016.

YU, G. et al. ggTree: an $r$ package for visualization and annotation of phylogenetic trees with 
their covariates and other associated data. Methods in Ecology and Evolution, v. 8, p. 28-36, 2017.

YU, G. et al. Two Methods for Mapping and Visualizing Associated Data on Phylogeny Using Ggtree. Mol Biol Evol, v. 35, n. 12, 3041-3043, 2018 a.

YU, X. et al. Role of Toll-like receptor 2 in inflammation and alveolar bone loss in experimental peri-implantitis vs. Periodontitis. J Periodontal Res, v. 53, p. 98-106, 2018 b.

ZHAO, S. et al. Novel gentamicin resistance genes in Campylobacter isolated from humans and retail meats in the USA. J Antimicrob Chemother, v. 70, n. 5, p. 1314-21, 2015.

ZHOU, L. et al. Macrophages polarization is mediated by the combination of PRR ligands and distinct inflammatory cytokines. Int J Clin Exp Pathol, v. 8, n. 9, p. 10964-10974, 2015.

ZANKARI, E. et al. Identification of acquired antimicrobial resistance genes. J Antimicrob Chemother, v. 67, n. 11, p. 2640-4, 2012. 